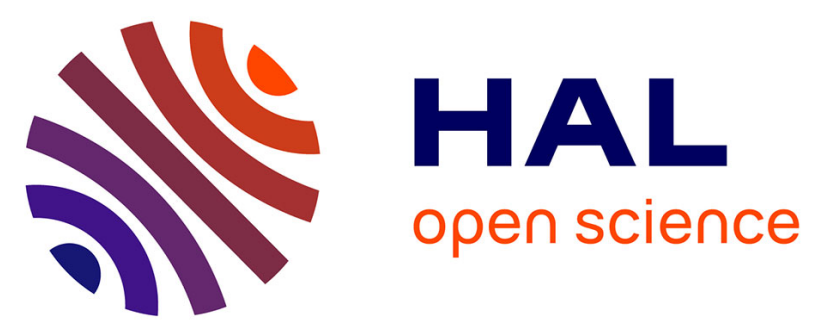

\title{
Supporting Information Homotrimerization Approach in the Design of Thrombospondin-1 Mimetic Peptides with Improved Potency in Triggering Regulated Cell Death of Cancer Cells
}

Thomas Denèfle, Elodie Pramil, Luis Gómez-Morales, Mikail D Levasseur, Eva Lardé, Clara Newton, Kenny Herry, Linda Herbi, Yann Lamotte, Estelle Odile, et al.

\section{- To cite this version:}

Thomas Denèfle, Elodie Pramil, Luis Gómez-Morales, Mikail D Levasseur, Eva Lardé, et al.. Supporting Information Homotrimerization Approach in the Design of Thrombospondin-1 Mimetic Peptides with Improved Potency in Triggering Regulated Cell Death of Cancer Cells. Journal of Medicinal Chemistry, 2019, 62 (17), pp.7656-7668. 10.1021/acs.jmedchem.9b00024 . hal-02367977

\section{HAL Id: hal-02367977 \\ https: / hal.sorbonne-universite.fr/hal-02367977}

Submitted on 18 Nov 2019

HAL is a multi-disciplinary open access archive for the deposit and dissemination of scientific research documents, whether they are published or not. The documents may come from teaching and research institutions in France or abroad, or from public or private research centers.
L'archive ouverte pluridisciplinaire HAL, est destinée au dépôt et à la diffusion de documents scientifiques de niveau recherche, publiés ou non, émanant des établissements d'enseignement et de recherche français ou étrangers, des laboratoires publics ou privés. 
1

\section{Homotrimerization Approach in the Design of Thrombospondin-1}

\section{Mimetic Peptides with Improved Potency in Triggering Regulated Cell}

\section{Death of Cancer Cells}

Thomas Denèfle, $\uparrow, \S, \exists$ Elodie Pramil , $\uparrow, \S, ", \exists$ Luis Gómez-Morales, $\uparrow, \S$,,$\exists$ Mikail D. Levasseur, $\dagger, \S$ Eva Lardé, $\dagger, \S$ Clara Newton, $\uparrow, \S$ Kenny Herry, ¥ Linda Herbi," Yann Lamotte, ¥, Estelle Odile, $\uparrow, \S$ Nicolas Ancellin, ¥ Pascal Grondin, $¥$ Ana-Carolina Martinez-Torres,ð Fabrice Viviani, ¥ Hélène Merle-Beral," Olivier Lequin, † Santos A. Susin," and

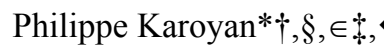

† Sorbonne Université, Ecole Normale Supérieure, PSL University, CNRS, Laboratoire des Biomolécules, LBM, 75005 Paris, France

$\S$ Sorbonne Université, Ecole Normale Supérieure, PSL University, CNRS, Laboratoire des Biomolécules, LBM, Site OncoDesign, 25-27 Avenue du Québec, 91140 Les Ulis, France $\in$ SiRIC CURAMUS (CANCER UNITED RESEARCH ASSOCIATING MEDICINE, UNIVERSITY \& SOCIETY) site de recherche intégrée sur le cancer IUC - APHP.6 - Sorbonne Université

ð Laboratory of Immunology and Virology, Autonomus University of Nuevo Leon, San Nicolas de los Garza, Mexico $¥$ OncoDesign, 25 Avenue du Québec, 91140 Les Ulis, France

" Cell Death and Drug Resistance in Lymphoproliferative Disorders Team, Centre de Recherche des Cordeliers, INSERM UMRS, 1138, Paris, France

$\ddagger$ Kayvisa, AG, Industriestrasse, 44, 6300 Zug, Switzerland

• Kaybiotix, GmbH, Zugerstrasse 32, 6340 Baar, Switzerland.

$\exists$ : equal contribution to this work

*E-mail: philippe.karoyan@sorbonne-universite.fr. Phone: +33 144274469 


\begin{abstract}
In order to optimize the potency of the first serum-stable peptide agonist of CD47 (PKHB1) in triggering regulated cell death $(\mathrm{RCD})$ of cancer cells, we designed a maturation process aimed to mimic the TSP-1/CD47 binding epitope trimeric structure. For that purpose, N-methylation-scan of PKHB1 sequence was realized to prevent peptide aggregation. Structural and pharmacological analyses were conducted in order to assess the conformational impact of these chemical modifications on the backbone structure and the biological activity. This structure-activity relationship (SAR) study led to the discovery of a highly soluble N-methylated peptide we termed PKT16. Afterward, this monomer was used for the design of a homotrimeric peptide mimic we termed $[\mathrm{PKT} 16]_{3}$ that proven to be tenfold more potent than its monomeric counterpart and we report hereafter its pharmacological evaluation in inducing cell death of adherent (A549) and nonadherent (MEC-1) cancer cell lines.
\end{abstract}

\title{
Introduction
}

A potential goal in the therapy of cancer disease is the selective triggering of cancer cell death. With this aim, the CD47 receptor is attracting considerable attention. This membrane glycoprotein is involved in many biological functions that are sometimes antagonistic, depending on the spatio-temporal expression of the receptor and its identified ligands (at least TSP1 and SIRP $\alpha$ ) together with lateral interactions of CD47 with other membrane receptors. ${ }^{1}$ On one hand, its binding to SIRP $\alpha$ on phagocytes serves as inhibitor of phagocytosis. ${ }^{2}$ As a result, cancer therapies using CD47:SIRP $\alpha$ interaction disrupting agents have been developed and some of them are currently under clinical investigations. ${ }^{3}$ On the other hand, some studies are focusing on targeting the TSP-1:CD47 interaction, identified as a key signaling integrator of tumor progression. ${ }^{4}$ With this aim, a peptide mimic of CD47, termed TAX2 and targeting TSP1, proven to display promising antiangiogenic, antitumor and antimetastatic properties in vivo in preclinical mouse models of childhood neuroblastoma. ${ }^{5}$ As for us, we focused our attention on the ability of the TSP1:CD47 ligation reported to induce regulate cell death ${ }^{6}$ and we recently described the first serum stable agonist peptide PKHB1 ${ }^{7,8}$ mimicking the CD47 binding epitope (i.e. RFYVVMWK) of thrombospondin-1 (TSP-1). This peptide was proven to be efficient in triggering selective regulated cell death (RCD) of many adherent and non-adherent cancer cell lines while sparing normal cells. The molecular mechanism triggered by PKHB1 in CLL (a caspase independent cell death mediated by sustained activation of PLC $\gamma 1$ leading to an intracellular $\mathrm{Ca}^{2+}$ overload) was highlighted and the stimulation of CD47 appeared key in the cytotoxicity 
induced by this peptide since the disruption of the peptide-CD47 interaction by a fusion protein designed to specifically bind CD47 led to the inhibition of cytotoxicity. ${ }^{7}$ The direct interaction between our peptide and CD47 in its native environment was studied using an active site-directed covalent probe approach. ${ }^{8 \mathrm{a}}$ Its capacity to induce tumor regression in a xenografted immunodeficient NSG mice CLL model ${ }^{7}$ together with its ability to induce tumor complete remission in a BALB/C immunocompetent mice model, activating in that later case an immunogenic cell death, was also demonstrated..$^{9}$ It was concluded from these experiments that the PKHB1 treatment of tumor prolonged the life of the animals, without affecting the vital and lymphoid organs. Collectively, these results highlight the potential of using peptide strategies to target the ubiquitous CD47 receptor and may appear as complementary to the use of monoclonal antibodies. ${ }^{3}$ However, even though PKHB1 appears as a promising tool, we remain aware that optimization of its effectiveness could be an asset in order to reach the standardized requirements in terms of nanomolar potency in peptide-based drug development. ${ }^{10}$ Therefore, an affinity maturation process capable of increasing the potency of the peptide for its target would be invaluable. Since the X-ray structure of the TSP-1/CD47 complex has not been solved to date, the lead optimization of medicinal peptides remains a fastidious task involving a long and iterative strategy. ${ }^{11}$ Nevertheless, the homotrimeric structure of TSP-1, ${ }^{12}$ the multifunctional extracellular protein that we endeavor to mimic, prompted us to evaluate a homotrimerization strategy of our lead peptide, namely PKHB1. The implication of polyvalent interactions for the design and use of multivalent ligands and inhibitors has been nicely reviewed and demonstrated elsewhere. ${ }^{13}$ Typically, a peptide homomultimerization approach may be relevant since multivalent interactions are much stronger than monovalent interactions. ${ }^{14}$ To this aim, the click chemistry cycloaddition ${ }^{15}$ of an azido-derivative of PKHB1 was considered. ${ }^{16}$ This strategy has been recently validated by Saludes and co-workers in the design of a bradykinin derived peptide. ${ }^{17}$ First, we described herein the SAR study that led to the discovery of a new monomeric peptide as potent as PKHB1, but with better solubility properties. Secondly, we engaged this monomer through the homotrimerization process yielding a new highly potent trimeric peptide. Regarding the efficacy of our peptides to trigger cell death, two technics were used in parallel and correlated (in combination with microscopic observations), i.e. 1) the classical Flow Cytometry (FCM) combining the detection of Phosphatidylserine (PS) exposure on early apoptotic cells using Allophycocyanin labelled Annexin V and propidium iodide (PI) to distinguish dying cells from dead cells, ${ }^{18}$ and 2) the Real Time Cell Analyzer (RTCA), a technique using noninvasive electrical impedance monitoring reported to quantify cancer cell proliferation, viability, invasion and drug cytotoxicity in a label-free and real-time manner. ${ }^{19}$ This later one was chosen to evaluate the efficacy of our compounds on an adherent cancer cell line (A549) because of its easy implementation 
avoiding the cell harvesting methods required in FCM that are known to affect membrane integrity of adherent cancer cells and thus the proportion of apoptotic cells during detection. ${ }^{20}$ Nevertheless, both technics were used and showed good correlation in cell death detection. Although the design of our new peptide was based on PKHB1, we assumed that the homotrimeric nature of the peptide could trigger a RCD that does not involve the same pathway. Thus, to get further information of cell death type triggered by our new peptides, experiments were realized in presence of QVD.Oph (a broadspectrum caspase inhibitor), BAPTA (an external calcium chelator), U73122 (PLC $\gamma 1$ inhibitor), 2-APB and dantrolene (Intracellular calcium channels inhibitors). We report hereafter the results of these experiments that led to the discovery of two new and potent peptides we termed respectively PKT16 for the monomer and [PKT16 $]_{3}$ for the homotrimer.

\section{Results}

We recently described the first serum stable TSP-1:CD47 binding epitope peptide mimic, i.e. PKHB1, and its ability to trigger a caspase-independent $\mathrm{Ca}^{2+}$-mediated form of RCD on CLL cells from patients and MEC-1 cells, a non-adherent CLL cancer cell line, while sparing normal cells. ${ }^{7,8}$ The double AnnexinV/PI co-positive staining and the swelling of the endoplasmic reticulum observed during the cell death induced by this peptide ${ }^{7,8}$ led us to classify it as a "programmed necrotic" cell death pathway. ${ }^{8,21}$ Although effective in inducing a rapid and selective RCD of malignant cells, the potency of PKHB1 in terms of affinity and activity remained to be improved. To this end, an homotrimerization strategy was considered using a click chemistry approach, a tertiary amine as a matrix and an aminopentanoic acid derivative as spacer. Unfortunately, because of aggregation propensities observed with PKHB1 in some buffers, this peptide was not suitable for the design of the homotrimer. This phenomenon was attributed to the chaotropic effect of the buffer used to solubilized the peptide 22 together with its $\beta$-strand structure, two parameters favoring the $\beta$-sheet nucleation. Thus, in order to limit this phenomenon, we went back to PKHB1 sequence to firstly design a monomer devoid of aggregation properties. This goal was realized with the help of a N-methyl scanning of the peptide backbone and SAR studies combining structural studies by NMR and CD, affinity measurement on MEC-1 cell membrane preparation using OctedRed as previously described, ${ }^{8}$ AnnV/PI cytotoxicity assays henceforth coupled to RTCA investigations. N-methylation of backbone amide was chosen for its renowned ability to disrupt peptide-peptide interactions that promote aggregation. ${ }^{23}$ Indeed, the replacement of the amide proton by a methyl group prevents the hydrogen bonding interactions that normally stabilize the $\beta$-sheet formation. In addition, $\mathrm{N}$-methyl amino acids prevent the close approach of $\beta$-strands because of steric hindrance, 


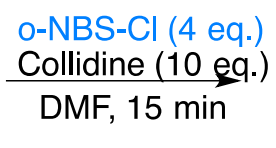

and favor $\beta$-strand structure in the peptide itself by locally restricting backbone conformation to extended structures. ${ }^{24}$ Of importance, backbone methylations also contribute to enhance resistance against proteolytic degradation. ${ }^{25} \mathrm{~N}-\mathrm{Methylated}$ amino acids have been used in several systems to control protein and peptide aggregation. ${ }^{26-28}$ Number of N-methylated peptides are currently being evaluated in clinical trials, displaying the promises of this chemical modification in delivering next generation of peptide-based drugs. ${ }^{29-32}$ We based the setting up of our N-Me sequence scanning on the straightforward site-selective approach developed by Kessler and colleagues, ${ }^{33}$ thus allowing the fast access to iterative $\mathrm{N}$-methylation of the backbone through Fmoc/tBu solid-phase synthesis technique. The complete methylation process was performed through a three-step methodology involving activation of the primary amine via sulfonylation, followed by the so-called methylation using dimethylsulfate and then elimination of the sulfonyl moiety with the help of $\beta$ mercaptoethanol (Figure 1).

Figure 1. On-resin synthesis of backbone N-methylated amino acids for the conception of a NMe library of PKHB1 analogs.<smiles>[R3]C(N)C(=O)N[C@@H]([R2])C(=O)NC([R7])C(=O)Oc1ccccc1</smiles>
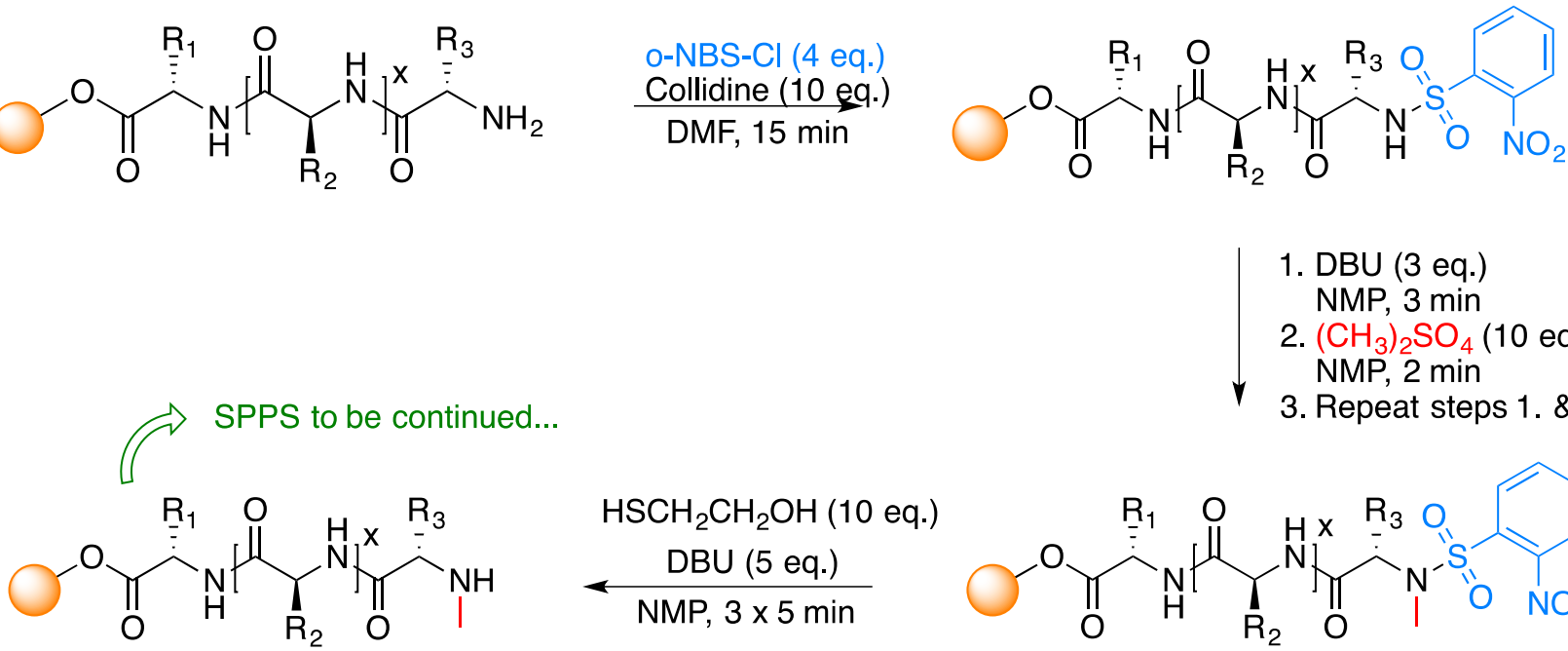

1. $\operatorname{DBU}(3$ eq.)

NMP, 3 min

2. $\left(\mathrm{CH}_{3}\right)_{2} \mathrm{SO}_{4}(10$ eq.)

NMP, 2 min

3. Repeat steps $1 . \& 2$.

Hereafter, we carried out a SAR study by systematic biological evaluations of each methylated sequences in terms of affinity and activity (Peptides 1 to 9 ). As described in our earlier work, ${ }^{8}$ such rational design was enabled by the development of a binding assay using MEC-1 cell membrane preparation in order to maintain the essential integrity of the targeted CD47 receptor. ${ }^{34}$ Thus, the affinities reported as apparent $\mathrm{Kd}$ estimations and exposed in Tables 1 correspond to the measure of peptide interaction with membrane preparation containing CD47 in the described conditions. We assume that all our peptides derive from PKHB1 and that any variations in their pharmacological profile will be due to a variation in their interaction efficiency with the CD47 receptor since we have previously demonstrated that the disruption of this 
interaction by a fusion protein specifically binding to CD47 led to inhibition of the cytotoxicity induced by PKHB1. ${ }^{7}$ In parallel to binding assays investigations, the ability of every peptide to selectively induce cell death was measured by Annexin-V (AnnV) and propidium iodide (PI) co-labeling on MEC-1 cancer cell line. The cytotoxicity activities are given as a percentage of tumor cell death and refer to the Annexin- $\mathrm{V}$ positive cells and were given at mean $\pm \mathrm{SD}$ (Tables 1). Other modifications were also evaluated (Peptides 10 to 16), to probe the potency of branched or aromatic side chains by substitution with Ile and Val, or Tyr (Table 1). Both terminal ends were also modified to explore the impact of extremities in terms of activity and affinity. To this end, C-termini acids were replaced by carboxamide moiety and N-termini amines were capped through acetylation. Furthermore, additional terminal D-Lys residues were removed to evaluate their biological impact.

Table 1. Sequence, Affinity, and Activity of the Peptides Designed from the NMe Scan and optimimisation.

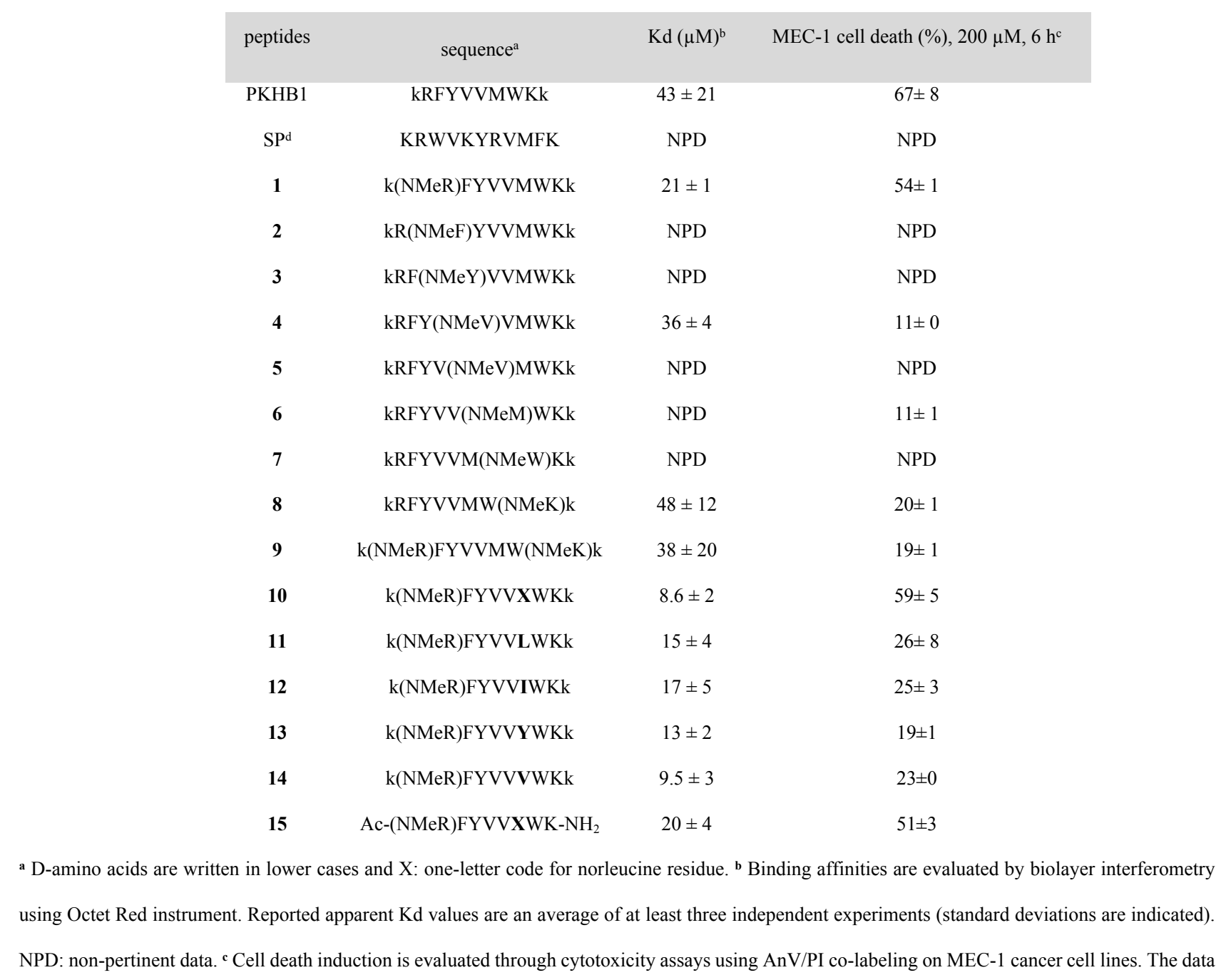


reported are an average value of at least three independent experiments (standard deviations are indicated). The sum of AnnV $+/ \mathrm{PI}-$ and AnnV $+/ \mathrm{PI}+$ events were considered for cell death. ${ }^{\mathbf{d}}$ SP: Scrambled Peptide ${ }^{35}$ (see Supporting Information) was evaluated at $300 \mu \mathrm{M}$.

Among all peptides designed and evaluated, peptide $\mathbf{1 0}$ not only appears to be the most soluble peptide but also presents a pharmacological profile very similar to that of PKHB1 with a slight improvement (3-fold) of its affinity. The conformational effects induced by $\mathrm{N}$-methylation might explain this improvement. Thus, the secondary structure of peptide $\mathbf{1 0}$ was investigated, first by CD spectroscopy. Figure $\mathbf{2 A}$ shows the CD spectra of peptide $\mathbf{1 0}$ and the parent peptide PKHB1. The spectrum of PKHB1 is characteristic of a random coil conformation with a negative minimum at $195 \mathrm{~nm}$. The spectrum of peptide $\mathbf{1 0}$ exhibits a similar minimum near $198 \mathrm{~nm}$ and another minimum around $215 \mathrm{~nm}$. This additional contribution may be due to the presence of $\beta$-sheet conformers. Indeed, the deconvolution of the CD spectrum allows an estimation of $14 \%$ population for $\beta$-sheet content in peptide $\mathbf{1 0 .}$

We next carried out NMR conformational studies to analyze the structural effects of N-methylation at the residue level. $1 \mathrm{H}, 13 \mathrm{C}, 15 \mathrm{~N}$ resonances of peptide $\mathbf{1 0}$ were assigned and revealed the presence of two sets of chemical shifts. The main chemical shift differences involved the $\mathrm{NMe}$ and $\mathrm{CH} \alpha$ resonances of NMeArg2 and also the HN resonances of residues Phe3 up to Val6. This chemical shift heterogeneity was ascribed to cis-trans isomerism of the tertiary amide group between Lys 1 and NMeArg2. The major form, which population was estimated to $91 \%$ from intensity ratios, corresponds to the trans isomer, as evidenced by a strong ROE between the NMe protons and H $\alpha$ of Lys1. The conformation of the major trans form was compared to PKHB1 by examining chemical shifts, J coupling constants and ROEs. The structure of PKHB1 was previously shown to be highly flexible with some propensity to adopt extended backbone conformations for the FYVV segment containing aromatic and $\beta$-branched residues. ${ }^{8}$ The comparison of peptide $\mathbf{1 0}$ and PKHB1 shows that most residues have very similar chemical shifts, except positions 2 and 7 corresponding to the N-methylation and the Metto-Nle substitution. $1 \mathrm{H} \alpha$ and $13 \mathrm{C} \alpha$ chemical shifts marginally differ from random coil values, indicating that PKT16 does not adopt stable regular secondary structures (Figure 2B). The four central residues FYVV exhibit $3 \mathrm{JHN}-\mathrm{H} \alpha$ values that tend to be higher than coil values ${ }^{36}$ (Figure $2 \mathrm{C}$ ) and have also strong sequential H $\alpha$-HN ROEs (data not shown), suggesting that extended conformations are significantly populated in this segment. The C-terminal part is characterized by lower intensity sequential H $\alpha-H N$ ROEs and the presence of sequential HN-HN ROEs (residues 7/8 and 9/10), indicating that it explores less extended conformations.

Altogether, these NMR parameters show that the conformational space of residues 3-10 is very similar in peptide $\mathbf{1 0}$ and PKHB1, a result that was somehow not inferred from CD study. The differences observed in the CD spectra must therefore 
be related to local structural perturbations induced by N-methylation and possibly, changes in the CD spectroscopic properties of the tertiary amide bond. ${ }^{37}$ We conclude that the $\mathrm{N}$-methylation restricts backbone conformational space only locally, around residues 1-2, and has no major effect on the global conformation of peptide $\mathbf{1 0}$ in segment 3-10. Overall, we observed that backbone N-methylation conferred very good solubility and the peptide did not aggregate nor in water neither in biological liquids (pure water, phosphate buffers and human serum), thereby leading to promising physicochemical features.

Figure 2. CD and NMR-based conformational study of peptide 10 and PKHB1. (A) CD spectra of peptide 10 and PKHB1. (B) Chemical shift deviations (CSD) from random coil values of $13 \mathrm{C} \alpha$ resonances. ${ }^{38}$ The same reference random coil values were used for non-canonical amino acids of PKT16 (i.e. Arg and Met, in place of NMeArg and Nle), explaining the larger CSD observed for positions 2 and 7. (C) Comparison of 3JHN-Ha coupling constants with corresponding coil values. ${ }^{36}$ The coil value of Met was used in place of Nle for peptide 10. Nle: three-letter code for norleucine residue.
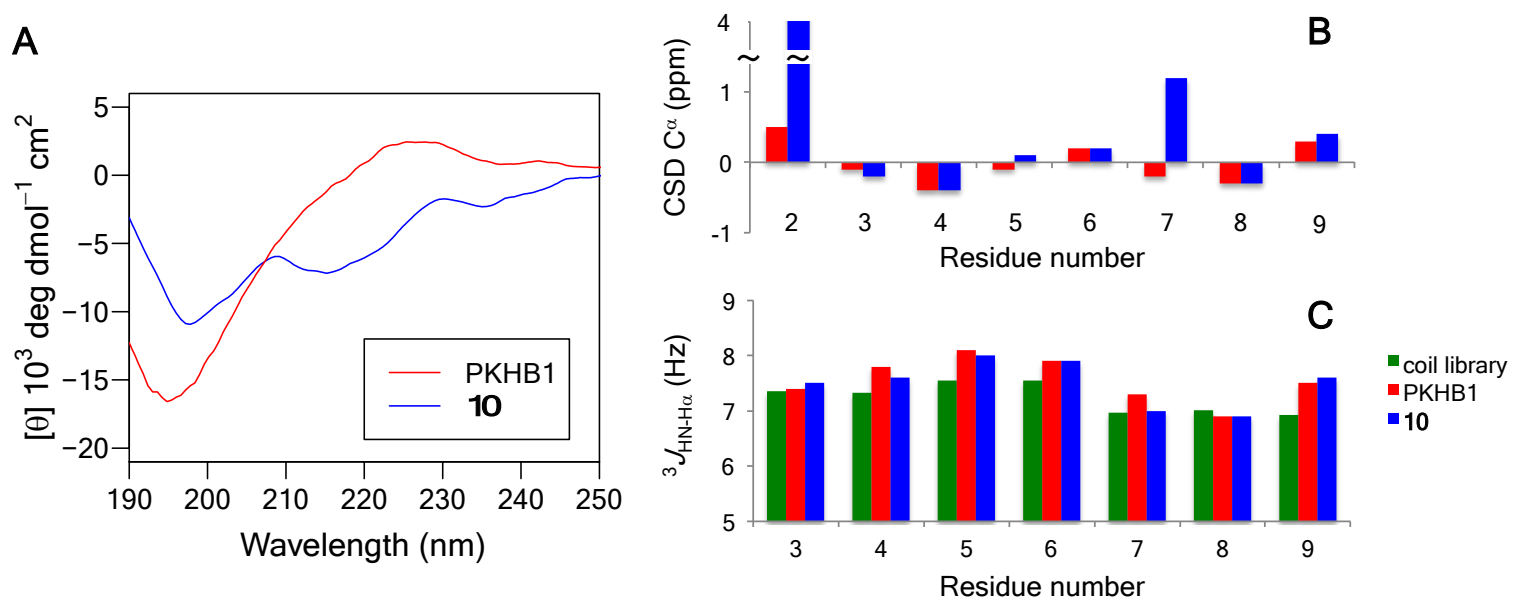

Consequently, with this new peptide 10 we termed PKT16, we considered the homotrimerization approach in order to improve its pharmacological efficacy. The design and synthesis of the analog were considered using a click chemistry strategy, a tertiary amine as a matrix and an aminopentanoic acid derivative as spacer (Figure 3). Based on CuAAC processes that were smartly applied in the field of peptide therapeutics, various reaction conditions have been tested to implement a convenient trimerization strategy onto scaffold. ${ }^{44}$ Surprisingly, the only one way to achieve this one-pot reaction was to use a mixture of methanol/acetonitrile as solvent and the copper I source was obtained from tetrakis acetonitrile complex. In addition, the incorporation of TBTA reagent for copper (I) stabilization was crucial to properly 
conduct the homotrimer formation. For this purpose, the monomeric PKT16 (k(NMeR)FYVVXWKk) sequence was synthesized on solid support using standard Fmoc chemistry (see Supporting Information) and coupled to the 5azidopentanoic acid ${ }^{42}$ used as a spacer bearing the azido group for click chemistry (Figure 3). After cleavage and purification, the unprotected PKT16- $\mathrm{N}_{3}$ peptide was used to perform the chemoselective click chemistry attachment onto tripropargyl amine matrix. Readers are reported to Experimental Section for further explanations regarding detailed reaction conditions. Successfully, the homotrimer built around PKT16 was soluble in water and did not form insoluble aggregates over time, thus confirming the enhanced physicochemical features. We thereby started evaluation of the activity of this new trimeric peptide object so-called $[\mathrm{PKT} 16]_{3}$.

Figure 3. General scheme for the preparation of $[\mathrm{PKT16}]_{3}$. Incorporation of the azido moiety via SPPS. Synthesis of the trimer is performed through click chemistry reaction for the attachment onto tri-alkyne scaffold. 
We first determined the affinity of $[\mathrm{PKT} 16]_{3}$ (on MEC-1 cell membrane preparation containing CD47 receptor) which proved to be about 40 -fold stronger compared to its monomeric precursor $\left(\mathrm{Kd}\left([\mathrm{PKT} 16]_{3}\right)=190 \pm 90 \mathrm{nM}\right.$ versus $\mathrm{Kd}(\mathrm{PKT} 16)=8.6 \pm 2 \mu \mathrm{M}$, see Supporting Information). Its potency to induce cell death was evaluated on two different cancer cell lines, i) the MEC-1 cells, an established TP53 dysfunctional CLL cell line and ii) the adherent A549 non-small cell lung cancer cell line. The cell death was evaluated using the classical FCM for MEC-1 cells (Figure 4) and A549 cells (Figure 5A). The RTCA technic was also used for A549 cell lines (Figure 5B). This later technic was chosen as a control because of its easy implementation for adherent cells avoiding the cell harvesting methods required in FCM that are known to affect membrane integrity of adherent cancer cells and thus the proportion of apoptotic cells during detection. ${ }^{20}$ 
In a first experiment, [PKT16 $]_{3}$ efficiency was evaluated in a dose-dependent manner and compared to that of PKHB1 and PKT16 on MEC-1 cells and the data are reported on figure 4A. Moreover, although the design of this new peptide was based on PKHB1 for which we reported a caspase-independent and $\mathrm{Ca}^{2+}$ mediated form of $\mathrm{RCD},{ }^{7,8}$ we assume that the homotrimeric nature of the peptide could trigger a different RCD pathway. Indeed, microscopic observations of cells treated with the different peptides (Figure 4B) highlighted the ability of this new homotrimeric peptide to induce cell aggregation. This might be explained by its multivalency promoting simultaneous interactions with receptors of different cells. Thus, in order to highlight the cell death mechanism in a second experiment, cells were pre-treated with QVD.OPh, a broad-spectrum caspase inhibitor, with BAPTA, an extracellular calcium chelator, U73122 (PLC $\gamma 1$ inhibitor), 2-APB and dantrolene (Intracellular calcium channels inhibitors), before incubation with the peptides (Figure 4C and Supplementary Table S4).

Figure 4. Low concentrations of $[\mathrm{PKT} 16]_{3}$ induce caspase-independent cell death regulated by $\mathrm{Ca}^{2+}$ in $\mathrm{MEC}-1$ cells. A. Comparison of cell death induction by different TSP1-mimetic peptides. Comparison of cell death induction by different TSP1-mimetic peptides. Cells were treated with the indicated peptide concentrations in complete medium and cell death was analysed by Ann-V/PI staining. Histograms represent the means $( \pm \mathrm{SD})$ of two independent experiments. B. Microscopic observation $(20 \mathrm{X})$ of cells treated with vehicle, PKHB1 $(200 \mu \mathrm{M})$, PKT16 $(200 \mu \mathrm{M})$ or $[\text { PKT16 }]_{3}(20$ $\mu \mathrm{M})$. C. Effect of pharmacological inhibition of caspases or calcium signalling in $[\mathrm{PKT} 16]_{3}$-induced cell death. Cells were preincubated with vehicle (Control), Q-VD-OPH (10 $\mu \mathrm{M})$, BAPTA (3 mM), U73122 (400 nM), 2-APB (60 $\mu$ M), dantrolene $(80 \mu \mathrm{M})$, or a $1 / 3$ combination of the last three (U73122 $133 \mathrm{nM}, 2-\mathrm{APB} 20 \mu \mathrm{M}$, dantrolene $27 \mu \mathrm{M})$, one hour before treatment with $[\text { PKT16 }]_{3}(5 \mu \mathrm{M})$, PKT16 $(50 \mu \mathrm{M})$ or PKHB1 $(50 \mu \mathrm{M})$ in serum free medium to limit peptides interactions with albumin (see supporting information Figure S3). Cell death was analysed by flow cytometry using AnnV/PI staining, and cell death index was obtained by normalizing to 1.0 the cell death induced by each peptide with its corresponding control (see supplementary information). Histograms represent the means $( \pm \mathrm{SD})$ of at least two independent experiments. Two-way ANOVA, $* * * \mathrm{P} \leq 0.0001 ; * * \mathrm{P} \leq 0.001 ; * \mathrm{P} \leq 0.05$. 
A

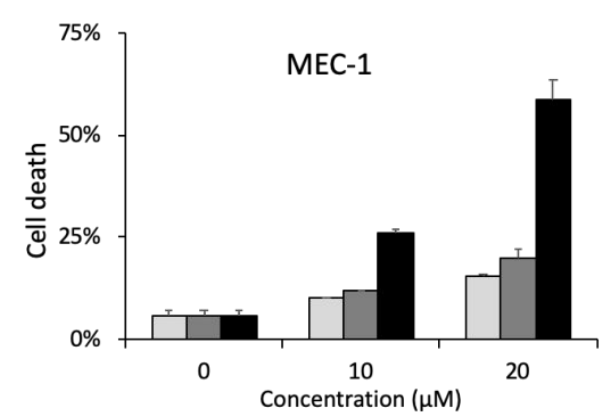

B

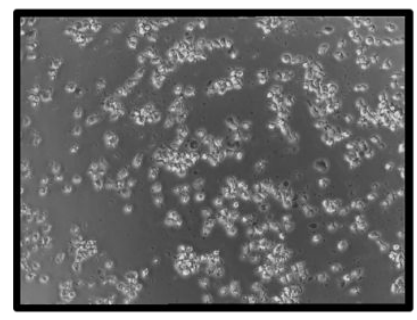

Vehicle

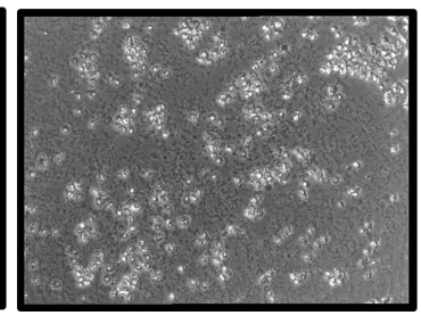

PKHB1

\section{C}
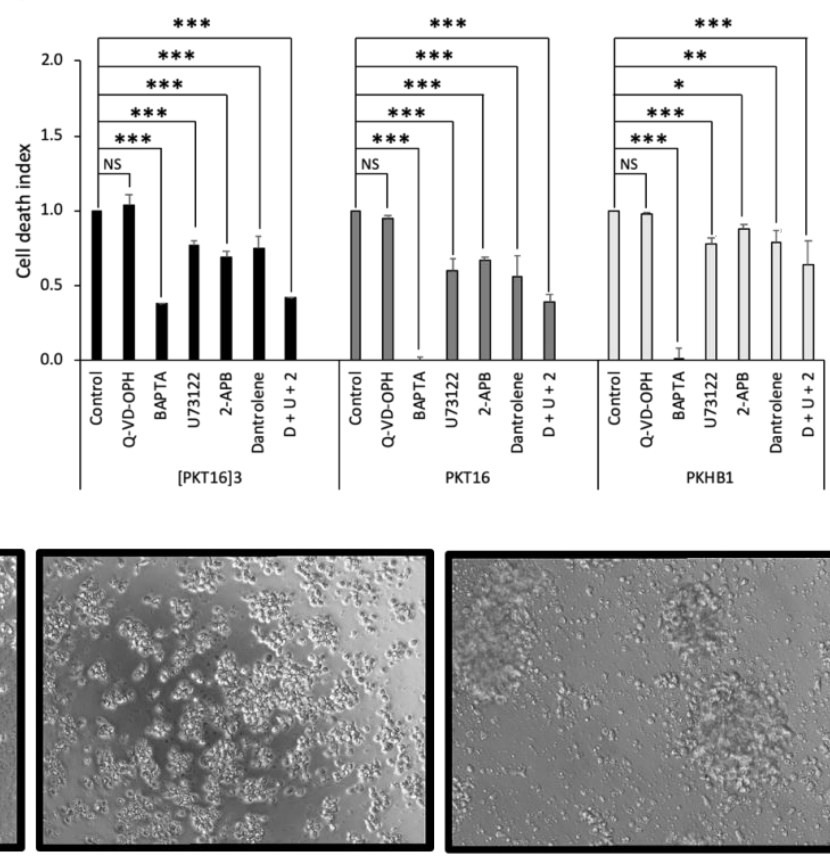

PKT16

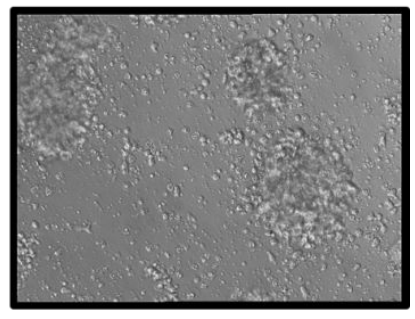

$\left[\right.$ PKT16 $_{3}$

$[\mathrm{PKT} 16]_{3}$ was a much more potent RCD inducer than its monomeric counterpart PKT16 and PKHB1 in MEC-1 cells.

Thus, its potency was also evaluated and compared to that of PKHB1 and PKT16 on the adherent human pulmonary alveolar epithelial cell line A549 and the data are reported in Figure 5A. Contrary to caspase inhibition, which had no effect on cell death induced by none of the three peptides, impairing $\mathrm{Ca}^{2+}$ signalling significantly decreased PKHB1-, PKT16- and [PKT16 $]_{3}$-induced cell death in A549 cells as well (Figure 5B-C, Supplementary Table S5).

Enhanced cell adhesion was also a relevant feature of [PKT16 $]_{3}$-induced RCD in A549 cells, which strongly stuck to the well surface after treatment. In fact, cell collection from the well prior to cell death analysis was a highly challenging task, since trypsin was not very efficient to remove a subpopulation of cells with morphological features characteristic of [PKT16 $]_{3}$-induced RCD (Supplementary Figure S2). Therefore, the RTCA technic was used as a control to evaluate the cell death induced by our new peptide because of its easy implementation avoiding the cell harvesting methods, which are known to affect membrane integrity of adherent cells and thus, the proportion of dead and dying cells during detection..$^{20}$ This way, $[\mathrm{PKT} 16]_{3}$ efficacy was also characterized using RTCA with increasing peptides concentrations for up to $24 \mathrm{~h}$ (Figure 5C) together with measurement of the release of AK (see Figure S5C in Supporting Information) and compared them to known cytotoxic concentrations of PKHB1 and PKT16 (Figure 5D). 
Figure 5. $[\mathrm{PKT16}]_{3}$ induce caspase-independent cell death regulated by $\mathrm{Ca}^{2+}$ in A549 cells. A. Comparison of cell death induction by different TSP1-mimetic peptides. Cells were treated with the indicated peptide concentrations in complete medium and cell death was analysed by Ann-V/PI staining. Histograms represent the means ( \pm SD) of two independent experiments. B. Effect of pharmacological inhibition of caspases or calcium signalling in $[\text { PKT16 }]_{3}$-induced cell death. Cells were preincubated with vehicle (Control), Q-VD-OPH (10 $\mu \mathrm{M})$, BAPTA (3 mM), U73122 (400 nM), $2-$ APB $(60 \mu \mathrm{M})$, dantrolene $(80 \mu \mathrm{M})$, or a $1 / 3$ combination of the last three (U73122 $133 \mathrm{nM}, 2$-APB $20 \mu \mathrm{M}$, dantrolene 27 $\mu \mathrm{M})$ one hour before treatment with [PKT16]3 $(10 \mu \mathrm{M})$, PKT16 $(100 \mu \mathrm{M})$ or PKHB1 $(100 \mu \mathrm{M})$ in serum free medium to limit peptides interactions with albumin (see supporting information Figure S3). Cell death was quantified by Ann-V/PI and trypan blue staining and cell death index was calculated as in Figure $4 \mathrm{C}$. Histograms represent the means $( \pm \mathrm{SD})$ of two independent experiments. Two-way ANOVA, ***P $\leq 0.0001 ; * * \mathrm{P} \leq 0.001 ; * \mathrm{P} \leq 0.05$. C. Microscopic observation (20X) of cells treated with the correspondent inhibitors alone (Control) or with TSP-1 mimetic peptides. *Similar morphology was observed irrespective of the used peptide ([PKT16 $]_{3}$, PKT16, PHB1). D. Full kinetics with cell index parameter on A549 cell line; 20000 cells/well; $n=4$ (repetitions in single experiment, two independent experiments); control in red (0,4\% DMSO), [PKT16 $]_{3}$ dose-response curves from $5 \mu \mathrm{M}$ to $40 \mu \mathrm{M}$. E. Comparison of the impedance signal of DMSO, 4NGG (negative control) ${ }^{7,8}$, PKHB1, PKT16 and [PKT16 $]_{3}$ after $24 \mathrm{~h}$ incubation at their respective LC50. 
A

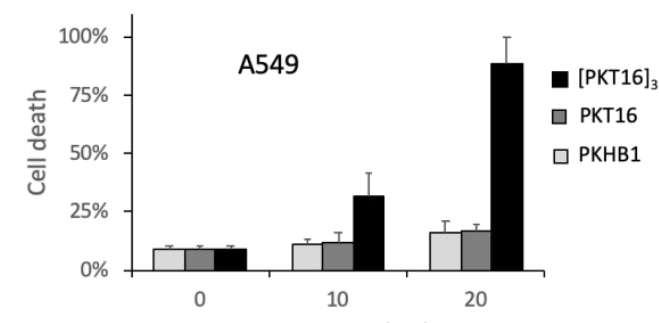

D

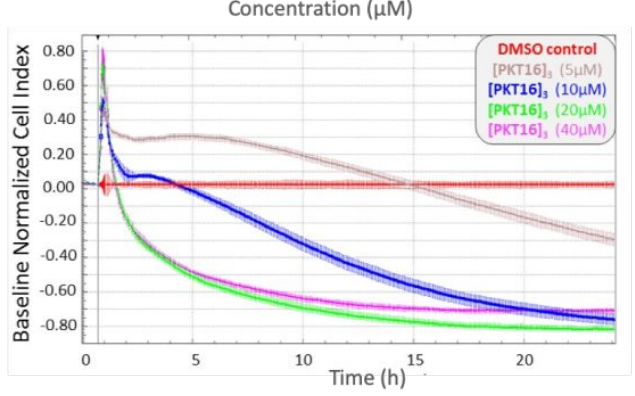

$\mathbf{E}$

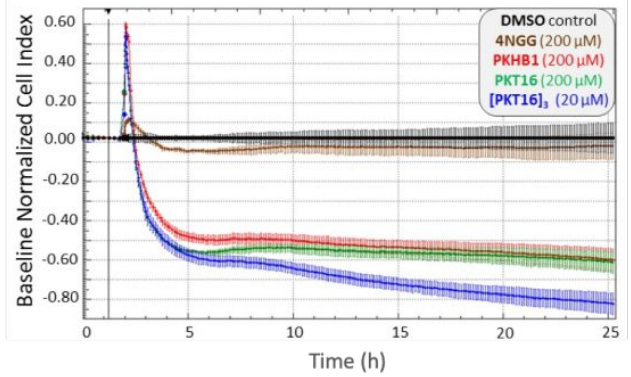

B
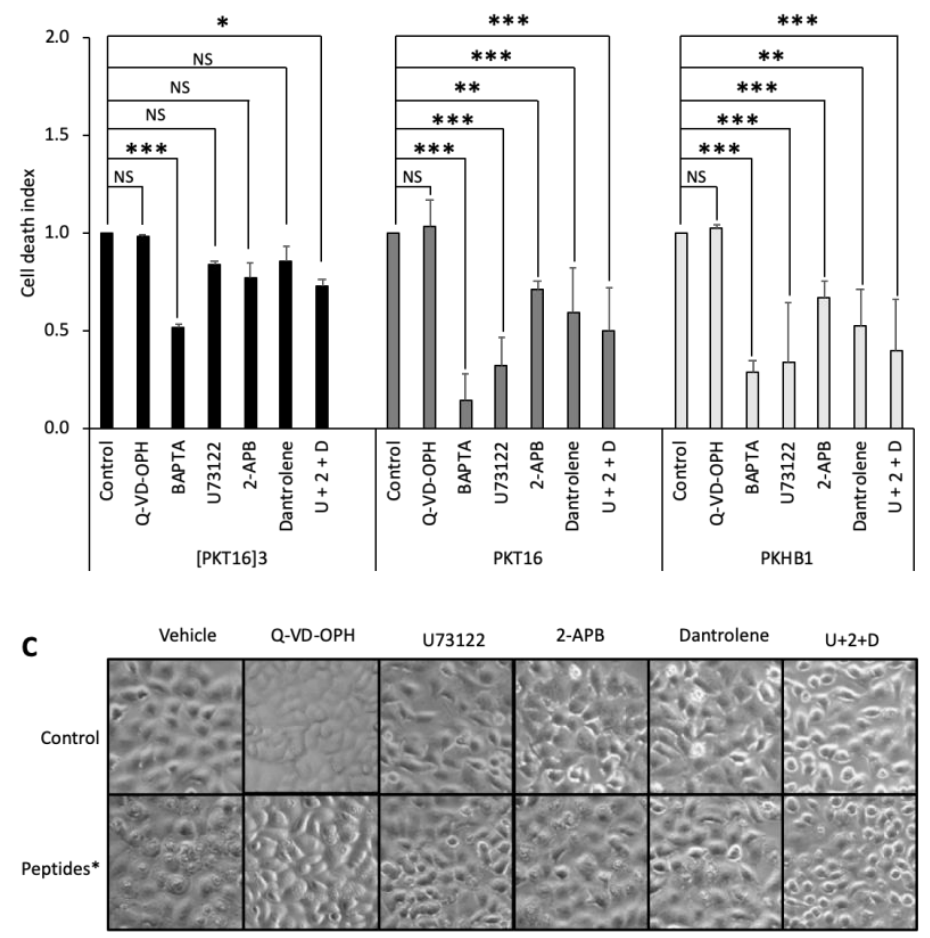

\section{Discussion}

The TSP1:CD47 ligation was reported to induce RCD at least in CLL cells ${ }^{6}$ and since few years, we have focused our attention in the design of peptide mimics of the TSP1:CD47 binding epitope. For that purpose, we implemented a SAR study aimed firstly to highlight the pharmacophores involved in this interaction. We reported that the crucial pharmacophores were not only restricted to the VVM motif but involved mainly the FYVV sequence. ${ }^{8}$ These studies led to the design of PKHB1, the first serum stable agonist peptide ${ }^{7,8}$ mimicking the CD47 binding epitope (i.e. RFYVVMWK) of thrombospondin-1 (TSP-1). PKHB1 sequence appeared key for its activity since a scrambled peptide (SP, KWVKYRVMFK, see Table 1$)^{35}$ has no affinity for membrane preparation nor cell death activities under the same conditions. PKHB1 was proven to be efficient in triggering cell death selectively in many adherent and non-adherent cancer cell lines while sparing normal cells. The molecular mechanism triggered by PKHB1 (a caspase independent cell death mediated by sustained activation of PLC $\gamma 1$ leading to an intracellular $\mathrm{Ca}^{2+}$ overload) was highlighted and the stimulation of CD47 appeared key in the cytotoxicity induced by this peptide since the disruption of the peptide-CD47 
interaction by a fusion protein designed to specifically bind CD47 led to the inhibition of cytotoxicity. ${ }^{7}$ Its potency was also demonstrated in vivo in mice models at a dose of $10 \mathrm{mg} / \mathrm{Kg} .{ }^{7,9}$ However, even though PKHB1 appears as a promising tool, its high in vitro LC50 $(200 \mu \mathrm{M})$ that might be considered as a drawback in drug development, led us to design and explore an optimization process. Since the X-ray structure of the TSP-1/CD47 complex has not been solved to date, a multimerization approach was investigated considering that the homotrimeric structure of TSP-1 did not happened by accident but is rather linked to evolution enabling TSP-1 to interact simultaneously with multiple receptors.

The design of the homotrimer was firstly based on PKHB1 structure (See Supporting Information) but because of aggregation propensities observed with PKHB1 and its trimer in some buffers, we concluded that this peptide was not suitable for our purpose. Thus, in order to limit this phenomenon, we went back to PKHB1 structure and realized a Nmethyl scanning of its sequence since N-methylation of backbone is known to disrupt peptide-peptide interactions that promote aggregation. The implementation of the NMe scan enabled the identification of key positions for amide backbone modification (Table 1). Firstly, we observed that all residues are not in capacity to accept N-methylation. Notably, when dealing with the FYVV segment, previously identified as the peptide pharmacophore, ${ }^{8}$ methylation of the backbone ultimately yielded to a complete drop in activity, as observed with peptides $\mathbf{2}, \mathbf{3}, \mathbf{4}$ and $\mathbf{5}$, thus confirming that structural information included in this 4-residues motif is crucial for CD47 engagement. Furthermore, we observed here that the only position that can be methylated without dramatic decrease in efficacy is the Arg2 since the peptide 1 retains full affinity and similar range of activity to PKHB1. To evaluate the impact of multiple backbone methylations, the data observed with peptide $\mathbf{1}$ and $\mathbf{8}$ led us to design the di-N-methylated peptide $\mathbf{9}$. This peptide, which has undergone two successive N-methylations at Arg2 and Lys9, presented a pharmacological profile similar to peptide 8. Thus, confirming that, unlike the suitable Arg2 position, N-methylation of Lys9 is deleterious as observed with peptide 8 . These data indicated that a single methylation might be sufficient to prevent peptide aggregation while maintaining efficiency. Actually, alike Pro residue, N-methylation is known to favor turn secondary structures in peptide sequences, thereby leading to disruption of the desired extended conformation. ${ }^{39}$ According to the NMe scan results, Arg2 is identified as the key amino acid to suitably accept backbone N-methylation. In addition, we also introduced chemical modifications into peptide 1 sequence, for instance Met7 was already been shown to be readily replaceable by its all-hydrocarbon counterpart, namely Nle. ${ }^{8}$ This modification was proposed to avoid a possible oxidation of sulfur atom of the Met side chain that might lead to a decreased potency as observed in the case of tachykinines. ${ }^{40}$ This was demonstrated by the synthesis and 
biological evaluation of the sulfoxide and sulfone derivatives of PKHB1 that proved to be totally inactive (see PKHB1$\mathrm{SO}$ and $\mathrm{PKHB} 1-\mathrm{SO}_{2}$ related data given in Supporting Information).

Regarding the SAR study realized to probe i) the potency of branched or aromatic side chains by substitution with Ile, Val, and Tyr or ii) to explore the impact of extremities in terms of activity and affinity (Table 1), results show that only amino acids presenting linear side chains are suitable to mimic Met7. Indeed, branched (Ile and Val) and aromatic residues (Tyr) are deleterious for peptide efficacy as observed with peptides 11, 12, 13 and 14, suggesting that the CD47 binding pocket interacting with these side chains is rather small since it only accepts linear moieties. Nevertheless, these data have to be interpreted carefully since these modified peptides were prone to aggregation as suggested by their more hydrophobic profiles. Chemical modifications of extremities yielded to the potent peptide $\mathbf{1 5}$ but this peptide was not suitable for the design of the homotrimer requiring a free amine function at the N-terminus side.

Finally, peptide $\mathbf{1 0}$ for which the Arg2 residue is N-methylated and the Met7 is replaced by a Nle, was chosen for further investigation because of i) its structure suitable for further development ii) its potency similar to that of PKHB1 and iii) its higher solubility in all buffers tested. This crucial point was confirmed during the structural analyses realized by NMR and $\mathrm{CD}$ on peptide 10. Indeed, we observed by NMR that backbone N-methylation conferred very good solubility and the peptide did not aggregate nor in water neither in biological liquids (pure water, phosphate buffers and human serum), thereby leading to promising physicochemical features.

Consequently, with this peptide 10 we termed PKT16, the homotrimerization was investigated using a click chemistry strategy, a tertiary amine as a matrix and an aminopentanoic acid derivative as spacer (Figure 3). The synthesis was realized in a one-pot reaction for which the use a mixture of methanol/acetonitrile as solvent, a copper I source obtained from tetrakis acetonitrile complex and incorporation of TBTA reagent for copper (I) stabilization revealed crucial to properly conduct the homotrimer formation we termed $[\text { PKT16 }]_{3}$. Successfully, the homotrimer built around PKT16 was soluble in water and did not form insoluble aggregates over time, thus confirming the enhanced physicochemical features. We thereby started its pharmacological evaluation by firstly determining its affinity on MEC-1 cell membrane preparation containing CD47 receptor. Remarkably, we observed a significant synergistic effect that is not simply additive due to the 3-fold increased local concentration of PKT16 stretches. Indeed, the binding affinity of the homotrimer [PKT16] 3 (190 \pm $90 \mathrm{nM})$ revealed to be about 40 -fold stronger compared to its monomeric precursor $(8.6 \pm 2 \mu \mathrm{M})$. Its potency in triggering cell death was evaluated first on the MEC-1 cells and compared to the monomeric PKHB1 and PKT16 in a dose-dependent manner (Figure 4A). The LC50 was reached at $20 \mu \mathrm{M}$ for the homotrimer while $200 \mu \mathrm{M}$ were required with the monomers 
to reach same efficacy (see Table 1). Thus, the novel N-methylated trimer enables a 10-fold higher induction of cell death, thereby confirming the synergistic effect allowed by multivalency. Of note, the observed discrepancy between activity and affinity is linked to the experimental conditions that are different between binding experiments and cell death experiments. The binding experiments are performed with cell membrane preparation in a simple PBS buffer whereas the cell death experiments are performed with cells incubated in advanced RPMI media containing albumin. Albumin binds low-molecular-weight molecules, including proteins and peptides and thus affects the free peptide concentration required for cell death experiments (see Supporting Figure S3). ${ }^{41}$ The potency of the homotrimer to induce cell death was also evaluated on the adherent A549 cancer cell line (Figure 5). First, the potency was evaluated in a dose-dependent manner and compared to that of PKHB1 and PKT16 as for MEC-1 cells and the data are reported on figure 5A. From these experiments, we can conclude that the homotrimer is much more potent than the monomers and its LC50 is between 10 and $20 \mu \mathrm{M}$. Furthermore, microscopic observation highlighted a peculiar behavior of the homotrimeric peptide (Figure 4B and supplementary Figure S2). Indeed, compared to PKHB1 and PKT16 at $200 \mu \mathrm{M}$ for which dead cells were observed without cell aggregation, the homotrimer peptide led to cell aggregate that might be explained by its ability to establish multivalent interactions with receptors from different cells. Since this peculiar behavior might result in different cell death mechanism than the one described for PKHB1, ${ }^{7}$ cells were pre-incubated with QVD.OPh, BAPTA (an external calcium chelator), U73122 (PLC $\gamma 1$ inhibitor), 2-APB and dantrolene (Intracellular calcium channels inhibitors) before incubation with the three peptides, PKHB1, PKT16 and [PKT16] $]_{3}$ (Figure 4C and 5B). Together with $\mathrm{Ca}^{2+}$ chelation, inhibitions of PLC $\gamma 1$ or the $\mathrm{IP}_{3} \mathrm{R}$ or the ryanodine receptors significantly diminished PKHB1- and PKT16-induced cell death in both cell lines. However, using $[\mathrm{PKT} 16]_{3}$, inhibition of PLC $\gamma 1$ or the calcium channels alone caused a significant drop of cell death in MEC-1 cells, but only a slight decrease that was not significant in A549 cells. However, combined inhibition of PLC $\gamma 1$ mediated calcium signalling significantly decreased cell death in all cases. The previous suggests that PLC $\gamma 1$-mediated calcium overload is crucial for [PKT16 $]_{3}$ and its monomeric counterpart PKT16 to trigger RCD in the non-adherent MEC1 cells, as already described for PKHB1. However, in the adherent lung cancer cells, this may also be true for the monomeric peptides PKHB1 and PKT16, but it is not the case for [PKT16 $]_{3}$, in which PLC $\gamma 1$-mediated calcium signalling is only a partial modulator of RCD. Together with morphological observations, the double Ann/PI copositive staining observed during MEC-1 cell death induced by $[\mathrm{PKT} 16]_{3}$ led us to classify it as a programmed necrotic cell death pathway similar to that reported for PKHB1.7,8,21 To go further, in the case of A549 cells, a type of RCD sharing some biochemical and morphological features of [PKT16 $]_{3}$-induced RCD such as caspase-independence, ion-exchange dependence, 17 
enhanced cell substrate adhesion and focal ballooning of the perinuclear space was recently reported under the name of autosis. ${ }^{42}$ Among other similar cellular stimulus, autotic cell death can be triggered by a cell-penetrating autophagyinducing peptide (Tat-Beclin 1). Moreover, it has been recently demonstrated that targeting CD47 with a fusion protein approach $(\mathrm{SIRP} \alpha \mathrm{D} 1-\mathrm{Fc})$ induces autophagy in non-small cell lung cancer cells, including the A549 cell line ${ }^{43}$ However, autosis is defined by autophagy triggering, and it is an autophagy-dependent cell death mechanism regulated by the $\mathrm{Na}^{+} / \mathrm{K}^{+}$-ATPase pump, which were not assessed for the present work. Thus, further analysis is needed to know whether $[\mathrm{PKT} 16]_{3}$ induces autosis in A549 cells. Altogether, our results showing pharmacological inhibition of TSP1-mimetic peptides in MEC-1 and A549 cells highlight the molecular disparities among both cell types, which come from two different diseases, and demonstrate that TSP1-mimetic peptides can restore programmed cell death in both cases.

Since it was reported that the cell harvesting methods required in FCM affect membrane integrity of adherent cancer cells and thus the proportion of apoptotic cells during detection, ${ }^{20}$ cell death induced by $[\mathrm{PKT} 16]_{3}$ was also evaluated using the RTCA technic in a dose-dependent manner (Figure 5D) and compared to the cell index of PKHB1 and PKT16 at their respective LC50 (Figure 5E). Cell index were continuously recorded every minute for $24 \mathrm{~h}$ and treatments were realized $1 \mathrm{~h}$ after the beginning of the cell index recording (see arrow on Figure 5D and 5E). For all these experiments, the peptides additions provoked firstly a high increasing of impedance signal that was attributed to the calcium burst we already observed through CD47 receptor activation with PKHB1 in CLL cells. On figure 5D, the experiment realized in a dosedependent manner (from 5 to $40 \mu \mathrm{M}$ ) highlighted a rapid and profound diminution of the cell index upon $2 \mathrm{~h}$ treatments with 20 and $40 \mu \mathrm{M}$ peptide concentrations. These observations correlate with those realized by FCM. Indeed, the maximum diminution of the cell index was observed from $20 \mu \mathrm{M}$ that correspond to the approximative LC50 estimated for this cell line using the FCM. This ability of our peptide to induce the profound diminution of cell index was correlated to the loss of cell membrane integrity identified by measurement of the release of Adenylate Kinase (AK) (See Supporting Information, Figure S5D). The loss of cell membrane integrity is also reflected by the double Annexin-PI staining in FCM. Finally, impedance signals in cells treated with PKHB1, PKT16 or its trimer $[\mathrm{PKT} 16]_{3}$ were similar when cells were treated with their respective LC50 (Figure 5E). Again, even for PKHB1 and PKT16 monomers, the profound diminution of cell index was correlated to the loss of cell membrane integrity identified by measurement of the release of AK (See Supporting Information, Figure S5E). This technique is therefore effective and powerful to quickly and simply evaluate the potency of our compounds on adherent cancer cell lines. 
Herein and in conclusion, we designed a new series of soluble peptides mimicking the action of TSP-1 C-terminal binding domain, namely the selective induction of RCD in tumors. We initiated rational SAR studies that led to the discovery of mimetic peptides, we designed as the monomeric PKT16 and its trimeric analog [PKT16 $]_{3}$, both with improved pharmacological features, increased solubility, fitter structural properties and higher efficacy. Such refinements have been unlocked by the entire sequence scanning through amide backbone $\mathrm{N}$-methylation and the judicious substitution of key amino acids. In order to further ameliorate our lead properties, we set up a multivalency strategy through homotrimerization of active peptide stretches mounted onto a rigid small molecular scaffold. Preparation of the trimer object via click chemistry yielded a soluble biopolymer that presented deeply improved pharmacological parameters, in terms of activity and affinity. To our knowledge, this trimeric peptide is the strongest affine and active TSP-1 C-terminal binding domain mimetic peptide in triggering RCD through CD47 engagement in tumors. Many evidences urge us to propose programmed necroptic cell death as the cell death mechanism triggered by our peptide. However, the behavior of our homotrimer led us to propose a death mechanism comparable to autosis, which, however, remains to be characterized here. Overall, this work provides several insights of major importance for identifying potent therapeutic strategies in the design of new TSP-1 C-terminal binding domain mimetic peptides triggering RCD of cancer cells.

\section{Experimental Section}

\section{General chemistry}

\subsection{Peptide synthesis}

All the peptides were manually synthesized from Fmoc-protected amino acids utilizing standard solid phase peptide synthesis (SPPS) methods. Solid-phase peptide syntheses were performed in polypropylene Torviq syringes (10 or $20 \mathrm{~mL}$ ) fitted with a polyethylene porous disk at the bottom and closed with an appropriate piston. Solvent and soluble reagents were removed through back and forth movements. The appropriate protected amino acids were sequentially coupled using PyOxim/Oxyma as coupling reagents. The peptides were cleaved from the chlorotrityl or rink amide resin with classical cleavage cocktail TFA/TIS/H2O $(95: 2.5: 2.5)$. The crude products were purified using preparative scale 
HPLC. The final products were characterized by analytical LCMS and NMR. All tested compounds were TFA salts and were at least $95 \%$ pure. Detailed NMR studies were performed for the relevant peptides and assignment tables are provided in the Supporting Information.

\subsection{Site-selective N-Methylation of amide backbone}

Residues were N-methylated on solid-phase through Kessler's methodology: first, the free amino functionality was protected and activated with the o-nitrobenzenesulfonyl (o-NBS) group, then N-methylated using 1,8diazabicyclo[5,4,0]undec-7-ene (DBU) and dimethylsulfate (DMS), and finally deprotected (removal of o-NBS) by treating the resin with ß-mercaptoethanol and DBU.26

o-NBS Activation: a solution of o-NBS-Cl (4 eq.) and collidine (10 eq.) in NMP was added to the resin-bound free amine peptides and shaken for $15 \mathrm{~min}$ at room temperature. The resin was washed with NMP (5×).

N-Methylation with DBU and DMS: a solution of DBU (3 eq.) in NMP was added to the resin bound o-NBS-protected peptides and shaken for $3 \mathrm{~min}$. A solution of dimethylsulfate (10 eq.) in NMP was then added to the reaction mixture and shaken for $2 \mathrm{~min}$. The resin was filtered off, washed once with NMP and the N-methylation procedure repeated once more. The resin was washed with NMP $(5 \times)$.

o-NBS Removal: the resin bound N-Methyl-N-o-NBS-peptides was treated with a solution of ß-mercaptoethanol (10 eq.) and DBU (5 eq.) in NMP for 5 min. The deprotection procedure was repeated once more and the resin was washed with $\operatorname{NMP}(5 \times)$.

\subsection{Homotrimerization by solution phase click chemistry (CuAAC)}

Typically, pure azido peptide derivative ( $36 \mathrm{mg}, 19 \mu \mathrm{mol}, 3.6$ eq.) was taken up in $750 \mu \mathrm{L} \mathrm{MeOH}$ that was previously frozen and put on a vacuum pump to remove gas molecules and then purged with $\mathrm{N} 2$ for at least $30 \mathrm{~min}$. To this mixture was added tripropargylamine $(0.94 \mu \mathrm{L}, 6.7 \mu \mathrm{mol}, 1$ eq. $)$ in $250 \mu \mathrm{L} \mathrm{MeOH}$, followed by the addition of Tris[(1benzyl-1H-1,2,3-triazol-4-yl)methyl]amine (TBTA, $21 \mathrm{mg}, 40 \mu \mathrm{mol}, 6$ eq.) and Tetrakis (acetonitrile)copper(I) hexafluorophosphate ([(CH3CN)4Cu]PF6, $78 \mathrm{mg}, 203 \mu \mathrm{mol}, 30$ eq.). To this mixture was added MeCN dropwise (around 20 drops) to bring everything into solution, and the reaction was allowed to proceed in a round-bottom flask at room temperature under nitrogen flow with constant stirring for maximum $72 \mathrm{~h}$. The sample was quenched with $5 \mathrm{~mL} \mathrm{H} 2 \mathrm{O}$, 


\subsection{Purification}

Preparative scale purification of peptides was performed by reverse phase HPLC on a Waters system consisting of a quaternary gradient module (Water 2535) and a dual wavelength UV/visible absorbance detector (Waters 2489), piloted by Empower Pro 3 software using the following columns: preparative Macherey- Nagel column (Nucleodur HTec, C18, $250 \mathrm{~mm} \times 16 \mathrm{~mm}$ i.d., $5 \mu \mathrm{m}, 110 \AA$ ) and preparative Higgins analytical column (Proto 200, C18, $150 \mathrm{~mm} \times 20 \mathrm{~mm}$ i.d., $5 \mu \mathrm{m}, 200 \AA$ ) at a flow rate of $14 \mathrm{~mL} / \mathrm{min}$ and $20 \mathrm{~mL} / \mathrm{min}$, respectively. Small-scale crudes $(<30 \mathrm{mg}) \mathrm{were}$ purified using semipreparative Ace column (Ace 5, C18, $250 \mathrm{~mm} \times 10 \mathrm{~mm}$ i.d., $5 \mu \mathrm{m}, 300 \AA$ ) at a flow rate of $5 \mathrm{~mL} / \mathrm{min}$. Purification gradients were chosen to get a ramp of approximately $1 \%$ solution B per minute in the interest area, and UV 
detection was done at 220 and $280 \mathrm{~nm}$. Peptide fractions from purification were analyzed by LC-MS (method A or B depending of retention time) or by analytical HPLC on a Dionex system consisting of an automated LC system (Ultimate 3000) equipped with an autosampler, a pump block composed of two ternary gradient pumps, and a dual wavelength detector, piloted by Chromeleon software. All LC-MS or HPLC analyses were performed on C18 columns. The pure fractions were gathered according to their purity and then freeze-dried using an Alpha 2/4 freeze-dryer from Bioblock Scientific to get the expected peptide as a white powder. Final peptide purity $(>95 \%)$ of the corresponding pooled fractions was checked by LC-MS using method A.

\section{Peptide stability studies}

\subsection{Degradation assays in human serum \& mouse plasma}

To a mixture of $250 \mu \mathrm{L}$ of human serum (or mouse plasma) and $750 \mu \mathrm{L}$ of RPMI 1640 were added $20 \mu \mathrm{L}$ of the peptide DMSO stock solution at $10 \mathrm{mM}$. The mixture was incubated at $37^{\circ} \mathrm{C}$. Aliquots of $100 \mu \mathrm{L}$ were removed from the medium at different times, mixed with $100 \mu \mathrm{L}$ of TCA solution $(6 \%)$ and incubated at $4{ }^{\circ} \mathrm{C}$ for at least 15 min to precipitate all the serum proteins. After centrifugation at 12,000 rpm for $2 \mathrm{~min}, 50 \mu \mathrm{L}$ of the supernatant were transferred to an injection vial and analyzed by HPLC with a linear gradient of $\mathrm{MeCN}$ in water ( 5 to $95 \%+0.1 \%$ TFA). The relative concentrations of the remaining soluble peptides were calculated by integration of the absorbance at $220 \mathrm{~nm}$ as a function of the retention time (peak area).

\subsection{Stability under chymotrypsin and trypsin incubation}

A $0.6 \mathrm{~mL}$ microcentrifuge tube was charged with $180 \mu \mathrm{L}$ of phosphate buffer $\mathrm{pH} 7.4,10 \mu \mathrm{L}$ of enzyme $(0.05$ $\mathrm{mg} / \mathrm{mL}$ stock solution in phosphate buffer $\mathrm{pH}$ 7.4), $10 \mu \mathrm{L}$ of peptide (10 mM stock solution in DMSO). The resulting reaction mixture was capped and incubated at room temperature for 3 hours. $20 \mu \mathrm{L}$ of the crude reaction was quenched by addition of $180 \mu \mathrm{L}$ of $50 \%$ water: $50 \%$ acetonitrile and was subjected to LCMS analysis. 


\section{Biological assays}

\subsection{CD spectroscopy}

CD experiments were acquired on a Jasco J-815 CD spectropolarimeter with a Peltier temperature-controlled cell holder $\left(30^{\circ} \mathrm{C}\right)$ over the wavelength range $190-270 \mathrm{~nm}$. Peptide samples were prepared at a concentration of $50 \mu \mathrm{M}$ in 10 $\mathrm{mM}$ sodium phosphate buffer, $\mathrm{pH} 7.4$, using a quartz cell of $1 \mathrm{~mm}$ path length. Measurements were taken every $0.2 \mathrm{~nm}$ at a scan rate of $10 \mathrm{~nm} / \mathrm{min}$.

\subsection{NMR spectroscopy}

Lyophilized PKT16 peptide was dissolved at $1 \mathrm{mM}$ concentration in $550 \mu \mathrm{L}$ of H2O/D2O (90:10 v/v). Sodium 4,4-dimethyl-4-silapentane-1-sulfonate-d6 (DSS, from Sigma Aldrich) was added at a final concentration of $0.11 \mathrm{mM}$ for chemical shift calibration. NMR experiments were recorded on a Bruker Avance III $500 \mathrm{MHz}$ spectrometer equipped with a TCI $1 \mathrm{H} / 13 \mathrm{C} / 15 \mathrm{~N}$ cryoprobe with Z-axis gradient. NMR spectra were processed with TopSpin 3.2 software (Bruker) and analysed with NMRFAM-SPARKY program. ${ }^{45} 1 \mathrm{H}, 13 \mathrm{C}$, and $15 \mathrm{~N}$ resonances were assigned using $1 \mathrm{D} 1 \mathrm{H}$ WATERGATE, 2D 1H-1H TOCSY (DIPSI-2 isotropic scheme of $80 \mathrm{~ms}$ duration), 2D 1H-1H ROESY (300 ms mixing time), 2D 1H-13C HSQC, 2D 1H-15N HSQC, and 2D 1H-13C HMBC recorded at $25^{\circ} \mathrm{C} .1 \mathrm{H}$ chemical shift was referenced against DSS $1 \mathrm{H}$ signal and 13C, 15N chemical shifts were referenced indirectly. The chemical shift deviations were calculated as the differences between observed $1 \mathrm{H}, 13 \mathrm{C}$ chemical shifts and random coil values.33 $3 \mathrm{JHN}-\mathrm{H} \alpha$ coupling constants were measured on $1 \mathrm{D} 1 \mathrm{H}$ WATERGATE experiments recorded at 5 or $25^{\circ} \mathrm{C}$, or on $1 \mathrm{D}$ rows extracted from 2D TOCSY acquired with high resolution.

\subsection{Binding affinity measurements by biolayer interferometry}

The binding affinities of peptides for a membrane preparation from MEC-1 cells were measured by biolayer interferometry on an Octet RED96 System (Pall FortéBio Corp., Menlo Park, CA). This system monitors interference of 
light reflected from two sources (an internal reflection surface and the liquid/solid interface of a fiber optic sensor) to measure the rate of binding of molecules to the biosensor surface. MEC-1 cell membrane preparations were biotinylated with the EZ-Link NHS-PEG4-Biotin kit from Thermo-Scientific. Biotinylated membranes were then loaded onto SuperStreptavidin (SSA) biosensors (Pall FortéBio Corp.) at empirically determined concentrations. All affinity measurements were carried out in assay buffer (PBS with $0.2 \%$ BSA and $1 \%$ DMSO) at $30{ }^{\circ} \mathrm{C}$. The assay protocols are furtherly detailed in the Supporting Information.

\subsection{Cell death induction and pharmacological inhibition}

MEC-1 cells (an established CLL cell line with dysfunctional TP53 was used in the peptide screening assays) and A549 cells (an human alveolar basal epithelial adenocarcinoma cells) were maintained in complete medium (Advanced RPMI 1640 supplemented with 10\% fetal calf serum, $2 \mathrm{mM} \mathrm{L-glutamine,} \mathrm{and} 100 \mathrm{U} / \mathrm{mL}$ penicillin-streptomycin). Cell death was induced by treating MEC-1 cells for two hours or A549 for six hours with the indicated peptide concentrations. Etoposide ( $200 \mu \mathrm{M}, 24 \mathrm{~h})$ was used as positive control for p53- and caspase-dependent apoptosis. Cell death was measured by flow cytometry using Ann-V-APC $(0.1 \mu \mathrm{g} / \mathrm{mL}$; BD Biosciences) and PI $(0.5$ $\mu \mathrm{g} / \mathrm{mL}$; Sigma-Aldrich) staining or by the automated counting of trypan blue stained cells (Beckman Vi-CELL XR Cell Viability Analyzer). Q-VD-OPH (BioVision, Milpitas, CA, USA), BAPTA (CalbioChem; Merck, Billerica, MA, USA), U73122 (Sigma-Aldrich), 2-APB (Sigma-Aldrich) or dantrolene (Sigma-Aldrich) were used as indicated in figure legends. Two-way ANOVA were performed in GraphPad Prism 8.0 Software for statistical analysis.

\subsection{Cell viability evaluation by impedance measurement}

The xCELLigence system (ACEA Biosciences Inc.) monitors cellular events in real time without the incorporation of labels. The system measures electrical impedance across interdigitated microelectrodes integrated on the bottom of tissue culture E-Plates (16-well). The impedance measurement provides quantitative information about the biological status of the cells, including cell number, viability, and morphology. Regarding cell culture, human pulmonary epithelial from lung adenocarcinoma A549 cell line was grown in RPMI-1640 media supplemented with 10\% fetal bovine serum (FBS) and $2 \mathrm{mM} \mathrm{L-glutamine.} \mathrm{The} \mathrm{peptide} \mathrm{incubations} \mathrm{were} \mathrm{perfomed} \mathrm{in} \mathrm{RPMI-1640} \mathrm{medium} \mathrm{supplemented} \mathrm{with}$ $2 \mathrm{mM}$ L-glutamine and $0.2 \%$ Bovine Serum Albumin (incubation medium). For our experiments, $50 \mu \mathrm{L}$ of growth medium 
was added to each well of the 16-well E-plate to measure background levels of impedance. Then, $150 \mu \mathrm{L}$ of cell suspension was added to reach a cell density of 20000 cells/well. Cells were allowed to seed at room temperature for 30 min and then placed in the reader at $37{ }^{\circ} \mathrm{C}$ and $5 \% \mathrm{CO} 2$ for real-time recording of the cell index. The following day, the growth medium was removed and replaced with $100 \mu \mathrm{L}$ of the incubation medium. After the stabilization of the impedance signal for 2 hours, $100 \mu \mathrm{L}$ of incubation medium containing 2-fold peptide concentrations were added to the cells in order to reach the desired concentration in the well (direct addition of DMSO caused stress and damaged the cells). Negative controls were treated with the vehicle (DMSO at $0.4 \%$ final concentration). Each condition was tested in triplicates or quadruplicates and in two independent experiments. The cells were monitored every minute until $24 \mathrm{~h}$ after treatment.

\title{
Associated Content
}

The Supporting Information is available free of charge on the ACS Publications website at DOI: ......

Additional experimental details concerning (1) Synthesis and characterization of the peptides, (2) Stabilities studies, (3) Structural analyses, (4) binding affinity measurements, (5) Cell viability evaluation through impedance, (6) Flow cytometry, (7) Cell death induction, (8) Cancer cell lines used for in vitro experiments, and (9) Molecular formula strings

\section{Author information}

\author{
Corresponding Author \\ *E-mail: philippe.karoyan@sorbonne-universite.fr. Phone: +33144274469.
}

\section{Author Contributions}

TD, MDL, CN, EL and LGM performed all peptides syntheses. TD performed the binding and impedance experiments (with PG and EL for binding by Octed Red, with KH and NA for the Impedance). OL performed the structural studies and analyses. KH and LGM performed the in vitro PCD studies with A549 cell line. LGM, EP and LH performed the in vitro PCD studies with MEC-1 cell line. PK, H.M.-B. and S.A.S. supervised cell death experimental work. PK conceived and supervised this project, designed all the mimetic peptides and the experiments, interpreted all the data and wrote the draft of the manuscript. PK wrote the manuscript with the contribution of TD and LGM and the reviewing of the coauthors. 
Notes

The authors declare the following competing financial interest(s): The patent applications WO 2013182650 A1, 2013, PCT/EP2013/061727, PCT/EP2014/077335 and PCT/EP2017/061223 included results from this paper. The authors declare that no other competing interests exist.

\section{Acknowledgements}

This work was supported by the Labex Michem (TD Ph.D. thesis grant), IPV program (EP Ph.D thesis grant), French National Cancer Institute (Grant INCa-5839), ECOS nord (M17S01) and Curamus (08ACUR2018). PK is grateful to SATT Lutech and DGRTT from Sorbonne Université for helpful logistic and financial support and to Philippe Gene, Fabrice Viviani and Alexis Denis from Oncodesign for hosting the LBM team.

\section{Abbreviations Used}

AnV, Annexin-V; BALB/C mice, Bagg Albino mouse; CD47, cluster of differentiation 47; CLL, chronic lymphocytic leukemia; CSD, chemical shift deviation; FCM, Flow Cytometry; MEC-1, Chronic B Cell Leukemia; LC50, Lethal Concentration of drug leading to 50\% of cell death; NSG mice, NOD scid gamma mice; OR, OctetRed; PI, propidium iodide; PPI, protein-protein interaction; RCD, Regulated Cell Death, ROEs, Rotating Frame Overhauser Effet; RTCA, Real time cell analyzer; SPPS, Solid-Phase Peptide Synthesis; TSP-1, thrombospondin-1;

\section{References}


(1) Soto-Pantoja, D.R.; Kaur, S.; Roberts, D.D. CD47 Signaling Pathways Controlling Cellular Differentiation and Responses to Stress. Crit Rev Biochem Mol Biol, 2015, 50 53) :212-230.

(2) Oldenborg, P.A.; Zheleznyak, A.; Fang, Y.F.; Lagenaur, C.F.; Gresham, H.D.; Lindberg, F.P. Role of CD47 as a Marker of Self on Red Blood Cells. Science 2000, 288:2051-2054.

(3) (a) Chao, M.P.; Alizadeh, A.A.; Tang, C.; Myklebust, J.H.; Varghese, B.; Gill, S.; Jan, M.; Cha, A.C.; Chan, C.K.; Tan, B.T.; Park, C.Y.; Zhao, F.; Kohrt, H.E.; Malumbres, R.; Briones, J.; Gascoyne, R.D.; Lossos, I.S.; Levy, R.; Weissman, I.L.; Majeti, R. Anti-CD47 Antibody Synergizes with Rituximab to Promote Phagocytosis and Eradicate Non-Hodgkin Lymphoma. Cell 2010, 142:699-713. (b) Chao, M.P.; Weissman, I.L.; Majeti, R. The CD47-SIRPalpha Pathway in Cancer Immune Evasion and Potential Therapeutic Implications, Curr Opin Immunol 2012, 24: 225-232. (c) Willingham, S.B.; Volkmer, J.P.; Gentles, A.J.; Sahoo, D.; Dalerba, P.; Mitra, S.S.; Wang, J.; Contreras-Trujillo, H.; Martin, R.; Cohen, J.D.; Lovelace, P.; Scheeren, F.A.; Chao, M.P.; Weiskopf, K.; Tang, C.; Volmer, A.K.; Naik, T.J.; Storm, T.A.; Mosley, A.R.; Edris, B.; Schmid S.M.; Sun, C.K.; Chua, M.S.; Murillo, O.; Rajendram, P.; Cha, A.C.; Chin, R.K.; Kim, D.; Adorno, M.; Raveh, T.; Tseng, D.; Jaiswal, S.; Enger, P. Ø.; Steinberg, G.K.; Li, G.; So, S.K.; Majeti, R.; Harsh, G.R.; van de Rijn, M.; Teng, N.N.; Sunwoo, J.B.; Alizadeh, A.A.; Clarke, M.F.; Weissman, I.L. The CD47-Signal Regulatory Protein Alpha (SIRP $\alpha$ ) Interaction is a Therapeutic Target for Human Solid Tumors. Proc Natl Acad Sci US A 2012,109:6662-6667. (d) Soto-Pantoja, D.R.; Stein, E.V.; Rogers, N.M.; SharifiSanjani, M.; Isenberg, J.S.; Roberts, D.D. Therapeutic Opportunities for Targeting the Ubiquitous Cell Surface Receptor CD47. Expert Opin Ther Targets 2013,17: 89-103. (e) Tseng, D.; Volkmer, J. P.; Willingham, S. B.; Contreras-Trujillo, H.; Fathman, J. W.; Fernhoff, N. B.; Seita, J.; Inlay, M. A.; Weiskopf, K.; Miyanishi, M.; Weissman, I. L., Anti-CD47 Antibody-Mediated Phagocytosis of Cancer by Macrophages Primes an Effective Antitumor T-Cell Response. Proc Natl Acad Sci U S A 2013, 110 (27), 11103-11108. (f) Gholamin, S.; Mitra, S. S.; Feroze, A. H.; Liu, J.; Kahn, S. A.; Zhang, M.; Esparza, R.; Richard, C.; Ramaswamy, V.; Remke, M.; Volkmer, A. K.; Willingham, S.; Ponnuswami, A.; McCarty, A.; Lovelace, P.; Storm, T. A.; Schubert, S.; Hutter, G.; Narayanan, C.; Chu, P.; Raabe, E. H.; Harsh, G. t.; Taylor, M. D.; Monje, M.; Cho, Y. J.; Majeti, R.; Volkmer, J. P.; Fisher, P. G.; Grant, G.; Steinberg, G. K.; Vogel, H.; Edwards, M.; Weissman, I. L.; Cheshier, S. H. Disrupting the CD47-SIRPalpha Anti-Phagocytic Axis by a Humanized Anti-CD47 Antibody is an Efficacious Treatment for Malignant Pediatric Brain Tumors. Science translational medicine 2017, 9 (381) eaaf296. (g) Buatois, V.; Johnson, Z.; SalgadoPires, S. ; Papaioannou, A. ; Hatterer, E.; Chauchet, X.; Richard, F.; Barba, L.; Daubeuf, B.; Cons, L.; Broyer, L.; D’Asaro, M.; Matthes, T.; LeGallou, S.; Fest, T.; tarte, K.; Clarke Hinojosa, R.K.; Genescà Ferrer, E.; Ribera, J.M.; Dey, A.; Bailey, K.; Filedong, A.K.; Eissenberg, L.; Ritchey, J.; Rettig, M.; Dipersio, J.F.; Kosco-Vilbois, M.H.; Masternak, K.; Fischer, N.; Shang, 
L.; Ferlin, W.G. Preclinical Development of a Bispecific Antibody that Safely and Effectively Targets CD19 and CD47 for the Treatment of B-Cell Lymphoma and Leukemia. Mol Cancer Ther 2018,17:1739-1751. (h) Advani, R.; Flinn, I.; Popplewell, L.; Forero, A.; Bartlett, N.L.; Ghosh, N.; Kline, J.; Roschewski, M.; LaCasce, A.; Collins, G.P.; Tran, T.; Lynn, J.; Chen, J.Y.; Volkmer, J.P.; Agoram, B.; huang, J.; Majeti, R.; Weissman, I.L.; takimoto, C.H.; Chao, M.P.; Smith, S.M. CD47 Blockade by Hu5F9-G4 and Rituximab in Non-Hodgkin's Lymphoma. N Engl J Med 2018, 379:1711-1721. (i) Russ ,A.; Hua, A.B.; Montfort, W.R.; Rahman, B.; Riaz, I.B.; Khalid, M.U.; Carex, J.S.; Nawrocki, S.T.; Persky, D.; Anwer, F. Blocking "Don't Eat Me" Signal of CD47-SIRPalpha in Hematological Malignancies, an In-Depth Review. Blood Rev. 2018, 32:480-489.

(4) Sick, E.; Jeanne, A.; Schneider, C.; Dedieu, S.; Takeda, K.; Martiny, L. CD47 Update: a Multifaceted Actor in the Tumour Microenvironment of Potential Therapeutic Interest. Br J Pharmacol. 2012; 167:1415-1430.

(5) Jeanne, A.; Martiny, L.; Dedieu, S. Thrombospondin-Targeting TAX2 Peptide ImpairsTumor Growth in Preclinical Mouse Models of Childhood Neuroblastoma, Pediatr Res. 2017, 81 (3):480-488.

(6) (a) Mateo, V.; Lagneaux, I.; Bron, D.; Biron, G.; Armant, M.; Delespesse, G.; Sarfati, M. CD47 Ligation Induces CaspaseIndependent Cell Death in Chronic Lymphocytic Leukemia. Nature medicine 1999, 5, 11, 1277-1284. (b) Lih, C.J.; Wei, W.; Cohen, S.N. Txr1: a Transcriptional Regulator of Thrombospondin-1 that Modulates Cellular Sensitivity to Taxanes. Genes Dev. 2006, 20:2082-2095. (c) Lamy, L.; Foussat, A.; Brown, E. J.; Bornstein, P.; Ticchioni, M.; Bernard, A. Interactions Between CD47 and Thrombospondin Reduce Inflammation, The Journal of Immunology 2007, 178, 5930-5939. (d) Calippe, B.; Augustin, S.; Beguier, F.; Charles-Messance, H.; Poupel, L.; Conart, J.B.; Hu, S.J.; Lavalette, S.; Fauvet, A.; Rayes, J.; Levy, O.; Raoul, W.; Fitting, C.; Denèfle, T.; Pickering, M.C.; Harris, C.; Jorieux, S.; Sullivan, P.M.; Sahel, J.A.; Karoyan, P.; Sapieha, P.; Guillonneau, X.; Gautier, E.L.; Sennlaub, F. Complement Factor H Inhibits CD47-Mediated Resolution of Inflammation. Immunity 2017, 46 (2), 261-272.

(7) Martinez-Torres, A. C.; Quiney, C.; Attout, T.; Boullet, H.; Herbi, L.; Vela, L.; Barbier, S.; Chateau, D.; Chapiro, E.; NguyenKhac, F.; Davi, F.; Le Garff-Tavernier, M.; Moumne, R.; Sarfati, M.; Karoyan, P.; Merle-Beral, H.; Launay, P.; Susin, S. A., CD47 Agonist Peptides Induce Programmed Cell Death in Refractory Chronic Lymphocytic Leukemia B Cells via PLCGamma1 Activation: Evidence from Mice and Humans. PLoS medicine 2015, 12 (3), e1001796.

(8) (a) Karoyan, P.; Gomes-Morales, L.; Bellier, J.; Pramil, E.; Denèfle, T.; Rademaker, G.; Lardé, E.; Malgorn, C.; Kaminska, M.; Linhart, V.; Grillot, D.; Thai, R.; Merle-Beral, H.; Dedobbeleer, M.; Agirman, F.; Bellhacène, A.; Grondin, P.; Ancelin, N.; Martinez-Torres, A-C.; Susin, S.; Devel, L.; Castronovo, V. PKHB1, a TSP-1 Peptide Mimic, Interacts with CD47, Triggers Regulated Cell Death with Potent Anti-Cancer Activities In Vivo. Unpublished Results. (b) Denèfle, T.; Boullet, H.; Herbi, L.; 
Newton, C.; Martinez-Torres, A. C.; Guez, A.; Pramil, E.; Quiney, C.; Pourcelot, M.; Levasseur, M. D.; Lardé, E.; Moumné, R.;

Ogi, F. X.; Grondin, P.; Merle-Beral, H.; Lequin, O.; Susin, S. A.; Karoyan, P., Thrombospondin-1 Mimetic Agonist Peptides Induce Selective Death in Tumor Cells: Design, Synthesis, and Structure-Activity Relationship Studies. Journal of Medicinal Chemistry 2016, 59 (18), 8412-8421.

(9) (a) Uscanga-Palomeque, A.C.; Calvillo-Rodríguez, K.M.; Gómez-Morales, L.; Lardé, E.; Denèfle, T.; Caballero-Hernández, D.; Merle-Béral, H.; Susin, S. A.; Karoyan, P.; Martínez-Torres, A.-C.; Rodríguez-Padilla, C. CD47 Agonist Peptide PKHB1 Induces Immunogenic Cell Death in T-Cell Acute Lymphoblastic Leukemia Cells. Cancer Science 2019, 1, 256-268. (b) Martínez-Torres, A. C.;Calvillo-Rodríguez, K. M.; Uscanga-Palomeque, A. C.; Gómez-Morales, L.; Mendoza-Reveles, R.; Caballero-Hernández, D.; Karoyan, P.; Rodríguez-Padilla, C. PKHB1 Tumor Cell Lysate Induces Antitumor Immune System Stimulation and Tumor Regression in Syngenic Mice with Tumoral T Lymphoblasts. Journal of Oncology 2019, (219), ID 9852361.

(10) (a) Diao, L.; Meibohm, B., Pharmacokinetics and Pharmacokinetic-Pharmacodynamic Correlations of Therapeutic Peptides. Clinical pharmacokinetics 2013, 52 (10), 855-868. (b) Di, L., Strategic Approaches to Optimizing Peptide ADME Properties. The AAPS journal 2015, 17 (1), 134-143.

(11) (a) Henninot, A.; Collins, J. C.; Nuss, J. M., The Current State of Peptide Drug Discovery: Back to the Future? Journal of Medicinal Chemistry 2018, 61 (4), 1382-1414. (b) Tsomaia, N., Peptide Therapeutics: Targeting the Undruggable Space. European Journal of Medicinal Chemistry 2015, 94, 459-470. (c) Angell, Y. M.; Moos, W. H., Building on Success: A Bright Future for Peptide Therapeutics. Protein and Peptide Letters 2018, (25), 1-7.

(12) (a) Lawler, J., The Functions of Thrombospondin-1 and-2. Current Opinion in Cell Biology 2000, 12 (5), 634-640. (b) Anilkumar, N.; Annis, D. S.; Mosher, D. F.; Adams, J. C., Trimeric Assembly of the C-Terminal Region of Thrombospondin-1 or Thrombospondin-2 is Necessary for Cell Spreading and Fascin Spike Organisation. Journal of Cell Science 2002, 115 (Pt 11), 2357-2366. (c) Kvansakul, M.; Adams, J. C.; Hohenester, E., Structure of a Thrombospondin C-Terminal Fragment Reveals a Novel Calcium Core in the Type 3 Repeats. The EMBO Journal 2004, 23 (6), 1223-1233. (d) Adams, J. C.; Bentley, A. A.; Kvansakul, M.; Hatherley, D.; Hohenester, E., Extracellular Matrix Retention of Thrombospondin 1 is Controlled by its Conserved C-Terminal Region. Journal of Cell Science 2008, 121 (Pt 6), 784-795.

(13) Mammen, M.; Choi, S. K.; Whitesides, G. M., Polyvalent Interactions in Biological Systems: Implications for Design and Use of Multivalent Ligands and Inhibitors. Angewandte Chemie (International ed. in English) 1998, 37 (20), $2754-2794$. 
(14) (a) Cwirla, S. E.; Balasubramanian, P.; Duffin, D. J.; Wagstrom, C. R.; Gates, C. M.; Singer, S. C.; Davis, A. M.; Tansik, R. L.; Mattheakis, L. C.; Boytos, C. M.; Schatz, P. J.; Baccanari, D. P.; Wrighton, N. C.; Barrett, R. W.; Dower, W. J., Peptide Agonist of the Thrombopoietin Receptor as Potent as the Natural Cytokine. Science 1997, 276 (5319), 1696-1699. (b) Morcos, S.K. Contrast Media and Modern Imaging. European Journal of Radiology, 2006, 60 (3), $305-306$.

(15) Meldal, M.; Tornoe, C. W., Cu-Catalyzed Azide-Alkyne Cycloaddition. Chemical reviews 2008, 108 (8), $2952-3015$.

(16) Karoyan, P.; Launay, P.; Merle-Beral, H.; Susin, S. A. Method and Pharmaceutical Composition for Use in the Treatment of Cancer. WO 2013182650 A1, 2013.

(17) Saludes, J. P.; Morton, L. A.; Coulup, S. K.; Fiorini, Z.; Cook, B. M.; Beninson, L.; Chapman, E. R.; Fleshner, M.; Yin, H., Multivalency Amplifies the Selection and Affinity of Bradykinin-Derived Peptides for Lipid Nanovesicles. Molecular BioSystems 2013, 9 (8), 2005-2009.

(18) (a) Vermes, I.; Haanen, C.; Reutelingsperger, C. Flow cytometry of apoptotic cell death. J Immunol Methods. 2000, 243:167-190. (b) Crowley, L.C.; Scott, A.P.; Marfell, B.J.; Boughaba, J.A.; Chojnowski, G.; Waterhouse, N.J. Measuring Cell Death by Propidium Iodide Uptake and Flow Cytometry. Cold Spring Harb Protoc. 2016, (7), 647-651.

(19) (a) Giaever, I.; Keese, C. R., Monitoring Fibroblast Behavior in Tissue Culture with an Applied Electric Field. Proc Natl Acad Sci U S A 1984, 81 (12), 3761-3764. (b) Scott, C. W.; Peters, M. F., Label-Free Whole-Cell Assays: Expanding the Scope of GPCR Screening. Drug Discovery Today 2010, 15 (17-18), 704-716. (c) Webling, K.; Groves-Chapman, J. L.; Runesson, J.; Saar, I.; Lang, A.; Sillard, R.; Jakovenko, E.; Kofler, B.; Holmes, P. V.; Langel, U., Pharmacological Stimulation of GAL1R But Not GAL2R Attenuates Kainic Acid-Induced Neuronal Cell Death in the Rat Hippocampus. Neuropeptides 2016, 58, 8392. (d) Türker Şener, L.; Albeniz, G.; Dinç, B.; Albeniz, I. iCELLigence Real-Time Cell Analysis System for Examining the Cytotoxicity of Drugs to Cancer Cell Lines. Exp Ther Med. 2017, 14(3):1866-1870. (e) Ke, N.; Wang, X.; Xu, X.; Abassi, Y.A. The xCELLigence System for Real-Time and Label-Free Monitoring of Cell Viability". Methods Mol Biol. 2011, 740:33-43. (e) Xing, J.Z.; Zhu, L.; Jackson, J.A.; Gabos, S.; Sun, X.J.; Wang, X.B.; Xu, X. Dynamic Monitoring of Cytotoxicity on Microelectronic Sensors. Chem Res Toxicol. 2005,18(2):154-161.

(20) (a) Yan, G.; Efferth, T. Cell Harvesting Methods Affect Cellular Integrity of Adherent Cells During Apoptosis Detection. Anticancer Research, 2018, 38(12), 6669-6672.

(21) Galluzzi, L.; Vitale, I.; Aaronson, S. A.; Abrams, J. M.; Adam, D.; Agostinis, P.; Alnemri, E. S.; Altucci, L.; Amelio, I.; Andrews, D. W.; Annicchiarico-Petruzzelli, M.; Antonov, A. V.; Arama, E.; Baehrecke, E. H.; Barlev, N. A.; Bazan, N. G.; Bernassola, F.; Bertrand, M. J. M.; Bianchi, K.; Blagosklonny, M. V.; Blomgren, K.; Borner, C.; Boya, P.; Brenner, 30 
C.; Campanella, M.; Candi, E.; Carmona-Gutierrez, D.; Cecconi, F.; Chan, F. K.; Chandel, N. S.; Cheng, E. H.; Chipuk, J. E.; Cidlowski, J. A.; Ciechanover, A.; Cohen, G. M.; Conrad, M.; Cubillos-Ruiz, J. R.; Czabotar, P. E.; D'Angiolella, V.; Dawson, T. M.; Dawson, V. L.; De Laurenzi, V.; De Maria, R.; Debatin, K. M.; DeBerardinis, R. J.; Deshmukh, M.; Di Daniele, N.; Di Virgilio, F.; Dixit, V. M.; Dixon, S. J.; Duckett, C. S.; Dynlacht, B. D.; El-Deiry, W. S.; Elrod, J. W.; Fimia, G. M.; Fulda, S.; Garcia-Saez, A. J.; Garg, A. D.; Garrido, C.; Gavathiotis, E.; Golstein, P.; Gottlieb, E.; Green, D. R.; Greene, L. A.; Gronemeyer, H.; Gross, A.; Hajnoczky, G.; Hardwick, J. M.; Harris, I. S.; Hengartner, M. O.; Hetz, C.; Ichijo, H.; Jaattela, M.; Joseph, B.; Jost, P. J.; Juin, P. P.; Kaiser, W. J.; Karin, M.; Kaufmann, T.; Kepp, O.; Kimchi, A.; Kitsis, R. N.; Klionsky, D. J.; Knight, R. A.; Kumar, S.; Lee, S. W.; Lemasters, J. J.; Levine, B.; Linkermann, A.; Lipton, S. A.; Lockshin, R. A.; Lopez-Otin, C.; Lowe, S. W.; Luedde, T.; Lugli, E.; MacFarlane, M.; Madeo, F.; Malewicz, M.; Malorni, W.; Manic, G.; Marine, J. C.; Martin, S. J.; Martinou, J. C.; Medema, J. P.; Mehlen, P.; Meier, P.; Melino, S.; Miao, E. A.; Molkentin, J. D.; Moll, U. M.; Munoz-Pinedo, C.; Nagata, S.; Nunez, G.; Oberst, A.; Oren, M.; Overholtzer, M.; Pagano, M.; Panaretakis, T.; Pasparakis, M.; Penninger, J. M.; Pereira, D. M.; Pervaiz, S.; Peter, M. E.; Piacentini, M.; Pinton, P.; Prehn, J. H. M.; Puthalakath, H.; Rabinovich, G. A.; Rehm, M.; Rizzuto, R.; Rodrigues, C. M. P.; Rubinsztein, D. C.; Rudel, T.; Ryan, K. M.; Sayan, E.; Scorrano, L.; Shao, F.; Shi, Y.; Silke, J.; Simon, H. U.; Sistigu, A.; Stockwell, B. R.; Strasser, A.; Szabadkai, G.; Tait, S. W. G.; Tang, D.; Tavernarakis, N.; Thorburn, A.; Tsujimoto, Y.; Turk, B.; Vanden Berghe, T.; Vandenabeele, P.; Vander Heiden, M. G.; Villunger, A.; Virgin, H. W.; Vousden, K. H.; Vucic, D.; Wagner, E. F.; Walczak, H.; Wallach, D.; Wang, Y.; Wells, J. A.; Wood, W.; Yuan, J.; Zakeri, Z.; Zhivotovsky, B.; Zitvogel, L.; Melino, G.; Kroemer, G., Molecular Mechanisms of Cell Death: Recommendations of the Nomenclature Committee on Cell Death 2018. Cell Death and Differentiation 2018, 25 (3), $486-541$. (22) Long, F. A.; McDevit, W. F. Activity Coefficients of Nonelectrolyte Solutes in Aqueous Salt Solutions. Chemical Reviews 1952, $51(1), 119-169$.

(23) (a) Chatterjee, J.; Gilon, C.; Hoffman, A.; Kessler, H., N-Methylation of Peptides: a New Perspective in Medicinal Chemistry. Accounts of Chemical Research 2008, 41 (10), 1331-1342. (b) Chatterjee, J.; Rechenmacher, F.; Kessler, H., NMethylation of Peptides and Proteins: an Important Element for Modulating Biological Functions. Angewandte Chemie (International ed. in English) 2013, 52 (1), 254-269.

(24) (a) Tonelli, A. E., Conformational characteristics of L-proline oligomers. Journal of the American Chemical Society 1970, 92 (21), 6187-6190. (b) Tonelli, A. E., On the Stability of Cis and Trans Amide Bond Conformations in Polypeptides. Journal of the American Chemical Society 1971, 93 (26), 7153-7155. (c) Tonelli, A. E., Conformational Characteristics of Polypeptides 
Containing Isolated L-Proline Residues with Cis Peptide Bonds. Journal of molecular biology 1974, 86 (3), 627-635. (d) Vitoux, B.; Aubry, A.; Cung, M. T.; Marraud, M. N-Methyl Peptides VII. Conformational Perturbations Induced by N-Methylation of Model Dipeptides. Chemical biology \& drug design 1986, 27 (6), 617-632.

(25) Marelli, U. K.; Ovadia, O.; Frank, A. O.; Chatterjee, J.; Gilon, C.; Hoffman, A.; Kessler, H., Cis-Peptide Bonds: A Key for Intestinal Permeability of Peptides? Chemistry 2015, 21 (43), 15148-15152.

(26) Rajarathnam, K.; Sykes, B. D.; Kay, C. M.; Dewald, B.; Geiser, T.; Baggiolini, M.; Clark-Lewis, I., Neutrophil Activation by Monomeric Interleukin-8. Science 1994, 264 (5155), 90-92.

(27) Hughes, E.; Burke, R. M.; Doig, A. J., Inhibition of Toxicity in the Beta-Amyloid Peptide Fragment Beta-(25-35) Using NMethylated Derivatives: a General Strategy to Prevent Amyloid Formation. The Journal of biological chemistry 2000, 275 (33), 25109-25115.

(28) Kokkoni, N.; Stott, K.; Amijee, H.; Mason, J. M.; Doig, A. J., N-Methylated Peptide Inhibitors of Beta-Amyloid Aggregation and Toxicity. Optimization of the Inhibitor Structure. Biochemistry 2006, 45 (32), 9906-9918.

(29) Broggini, M.; Marchini, S. V.; Galliera, E.; Borsotti, P.; Taraboletti, G.; Erba, E.; Sironi, M.; Jimeno, J.; Faircloth, G. T.; Giavazzi, R.; D'Incalci, M., Aplidine, A New Anticancer Agent of Marine Origin, Inhibits Vascular Endothelial Growth Factor (VEGF) Secretion and Blocks VEGF-VEGFR-1 (flt-1) Autocrine Loop in Human Leukemia Cells MOLT-4. Leukemia 2003, $17(1), 52-59$.

(30) Kindler, H. L.; Tothy, P. K.; Wolff, R.; McCormack, R. A.; Abbruzzese, J. L.; Mani, S.; Wade-Oliver, K. T.; Vokes, E. E., Phase II Trials of Dolastatin-10 in Advanced Pancreaticobiliary Cancers. Investigational new drugs 2005, 23 (5), 489-493.

(31) Tamura, K.; Nakagawa, K.; Kurata, T.; Satoh, T.; Nogami, T.; Takeda, K.; Mitsuoka, S.; Yoshimura, N.; Kudoh, S.; Negoro, S.; Fukuoka, M., Phase I Study of TZT-1027, a Novel Synthetic Dolastatin 10 Derivative and Inhibitor of Tubulin Polymerization, which was Administered to Patients with Advanced Solid Tumors on Days 1 and 8 in 3-Week Courses. Cancer chemotherapy and pharmacology 2007, 60 (2), 285-293.

(32) Mas-Moruno, C.; Rechenmacher, F.; Kessler, H., Cilengitide: the First Anti-Angiogenic Small Molecule Drug Candidate Design, Synthesis and Clinical Evaluation. Anti-cancer agents in medicinal chemistry 2010, 10 (10), 753-768.

(33) Biron, E.; Chatterjee, J.; Kessler, H., Optimized Selective N-Methylation of Peptides on Solid Support. Journal of peptide science 2006, 12 (3), 213-219. 
(34) Rebres, R. A.; Vaz, L. E.; Green, J. M.; Brown, E. J., Normal Ligand Binding and Signaling by CD47 (Integrin-Associated Protein) Requires a Long Range Disulfide Bond Between the Extracellular and Membrane-Spanning Domains. The Journal of biological chemistry 2001, 276 (37), 34607-34616.

(35) The scramble peptide was designed using a scrambler tool (https://peptidenexus.com/article/sequence-scrambler, accessed Feb 10, 2019).

(36) Avbelj, F.; Grdadolnik, S. G.; Grdadolnik, J.; Baldwin, R. L., Intrinsic Backbone Preferences are Fully Present in Blocked Amino Acids. Proc Natl Acad Sci U S A 2006, 103 (5), 1272-1277.

(37) (a) Gordon, D. J.; Sciarretta, K. L.; Meredith, S. C., Inhibition of Beta-Amyloid (40) Fibrillogenesis and Disassembly of Beta-Amyloid (40) Fibrils by Short Beta-Amyloid Congeners Containing N-Methyl Amino Acids at Alternate Residues. Biochemistry 2001, 40 (28), 8237-8245. (b) Sciarretta, K. L.; Boire, A.; Gordon, D. J.; Meredith, S. C., Spatial Separation of Beta-Sheet Domains of Beta-Amyloid: Disruption of Each Beta-Sheet by N-Methyl Amino Acids. Biochemistry 2006, 45 (31), $9485-9495$.

(38) Lee, W.; Tonelli, M.; Markley, J. L., NMRFAM-SPARKY: Enhanced Software for Biomolecular NMR Spectroscopy. Bioinformatics 2015, 31 (8), 1325-1327.

(39) Sagan, S.; Karoyan, P.; Lequin, O.; Chassaing, G.; Lavielle, S., N- and C-Alpha-Methylation in Biologically Active Peptides: Synthesis, Structural and Functional Aspects. Current medicinal chemistry 2004, 11 (21), $2799-2822$.

(40) Sagan, S.; Karoyan, P.; Chassaing, G.; Lavielle, S., Further Delineation of the Two Binding Sites (R*(n)) Associated With Tachykinin Neurokinin-1 Receptors Using [3-Prolinomethionine(11)]SP Analogues. The Journal of biological chemistry 1999, 274 (34), 23770-23776.

(41) Plum, A.; Bjerring Jensen, L.; Bøggild Kristensen, J. In Vitro Protein Binding of Liraglutide In Human Plasma Determined by Reiterated Stepwise Equilibrium Dialysis, Journal Of Pharmaceutical Sciences, 2013, 102, 8, $2882-2888$.

(42) Liu, Y.; Shoji-Kawata, S.; Sumpter, R-M Jr.; Wei, Y.; Ginet, V.; Zhang, L.; Green, D.R.; Clarke P.G.; Puyal, J.; Levine, B. Autosis is a $\mathrm{Na}^{+}, \mathrm{K}^{+}$-ATPase-Regulated Form of Cell Death Triggered by Autophagy-Inducing Peptides, Starvation, and Hypoxia-Ischemia._Proc Natl Acad Sci US A. 2013 Dec 17;110(51), 20364-20371.

(42). Zhang, X.; Fan, J.; Wang, S.; Li, Y.; Wang, Y.; Li, S.; Luan, J.; Wang, Z.; Song, P.; Chen, Q.; Tian W.; Ju, D. Targeting CD47 and Autophagy Elicited Enhanced Antitumor Effects in Non-Small Cell Lung Cancer. Cancer Immunol Res. 2017, 5(5), $363-375$. 
(43) (a) Li, H.; Aneja, R.; Chaiken, I., Click Chemistry in Peptide-Based Drug Design. Molecules 2013, 18 (8), 9797-9817. (b) Angell, Y. L.; Burgess, K., Peptidomimetics via Copper-Catalyzed Azide-Alkyne Cycloadditions. Chemical Society reviews 2007, 36 (10), 1674-1689. (c) Schellinger, J. G.; Danan-Leon, L. M.; Hoch, J. A.; Kassa, A.; Srivastava, I.; Davis, D.; GervayHague, J., Synthesis of a Trimeric gp120 Epitope Mimic Conjugated to a T-Helper Peptide to Improve Antigenicity. Journal of the American Chemical Society 2011, 133 (10), 3230-3233. (d) Byrne, C.; McEwan, P. A.; Emsley, J.; Fischer, P. M.; Chan, W. C., End-Stapled Homo and Hetero Collagen Triple Helices: a Click Chemistry Approach. Chemical communications 2011, 47 (9), 2589-2591.

(44) Fernandez-Llamazares, A. I.; Garcia, J.; Adan, J.; Meunier, D.; Mitjans, F.; Spengler, J.; Albericio, F., The Backbone N(4-azidobutyl) Linker for the Preparation of Peptide Chimera. Organic letters 2013, 15 (17), 4572-4575.

(45) Wishart, D. S.; Bigam, C. G.; Holm, A.; Hodges, R. S.; Sykes, B. D., 1H, 13C and 15N Random Coil NMR Chemical Shifts of the Common Amino Acids. I. Investigations of Nearest-Neighbor Effects. Journal of biomolecular NMR 1995, 5 (1), 67-81.

\section{Table of Contents Graphic}

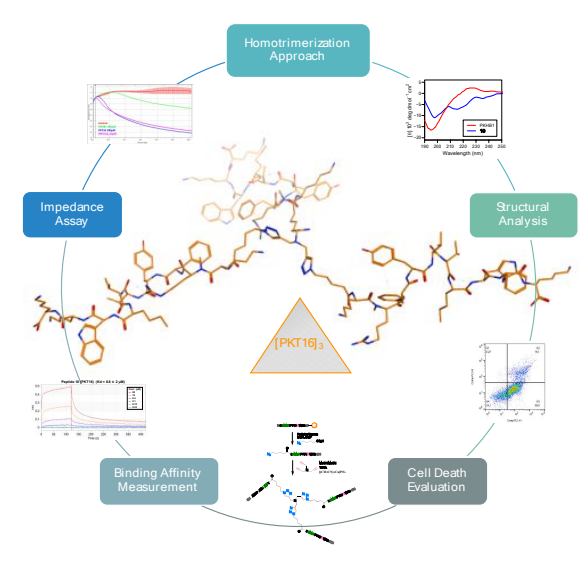

